\title{
iTRAQ-based proteomic analysis of myofibrillar contents and relevant synthesis and proteolytic proteins in soleus muscle of hibernating Daurian ground squirrels (Spermophilus dauricus)
}

\author{
Hui Chang ${ }^{1,2+}$, Shan-Feng Jiang ${ }^{1+}$, Kai Dang ${ }^{1}$, Hui-Ping Wang ${ }^{1}$, Shen-Hui $\mathrm{Xu}^{1}$ and Yun-Fang Gao ${ }^{1,2^{*}}$
}

\begin{abstract}
Background: Daurian ground squirrels (Spermophilus dauricus) deviate from significant increase of protein catabolism and loss of myofibrillar contents during long period of hibernation inactivity.

Methods: Here we use ITRAQ based quantitative analysis to examine proteomic changes in the soleus of squirrels in pre-hibernation, hibernation and post-hibernation states. The total proteolysis rate of soleus was measured by the release of the essential amino acid tyrosine from isolated muscles. Immunofluorescent analysis was used to determine muscle fiber cross-sectional area. Western blot was used for the validation of the quantitative proteomic analysis.

Results: The proteomic responses to hibernation had a 0.4- to 0.8-fold decrease in the myofibrillar contractile protein levels of myosin-3, myosin-13 and actin, but a 2.1-fold increase in myosin-2 compared to pre-hibernation group. Regulatory proteins such as troponin C and tropomodulin-1 were 1.4-fold up-regulated and 0.7-fold downregulated, respectively, in hibernation compared to pre-hibernation group. Moreover, 10 proteins with proteolytic function in hibernation, which was less than 14 proteins in the post-hibernation group, were up-regulated relative to the pre-hibernation group. The total proteolysis rates of soleus in hibernation and post-hibernation groups were significantly inhibited as compared with pre-hibernation group.
\end{abstract}

Conclusion: These findings suggest that the myofibrillar remodeling and partial suppression of myofibrillar proteolysis were likely responsible for preventing skeletal muscle atrophy during prolonged disuse in hibernation. This is the first study where the myofibrillar contents and relevant synthesis and proteolytic proteins in slow soleus was discussed based on proteomic investigation performed on wild Daurian ground squirrels. Our results lay the foundation for further research in preventing disuse-induced skeletal muscle atrophy in mammals.

Keywords: Daurian ground squirrel, Proteomic, Hibernation, Disuse atrophy, Myofibrillar protein, Synthesis and proteolysis

\footnotetext{
* Correspondence: gaoyunf@nwu.edu.cn

${ }^{\dagger}$ Equal contributors

${ }^{1}$ Key Laboratory of Resource Biology and Biotechnology in Western China (College of Life Sciences, Northwest University), Ministry of Education, Xi'an 710069, People's Republic of China

${ }^{2}$ Shaanxi Key Laboratory for Animal Conservation, Northwest University, Xi'an

710069, People's Republic of China
} 


\section{Background}

In mammals, skeletal muscle accounts for more than $40 \%$ of the mass of a given individual and provides critical functions in metabolism, energy expenditure, physical strength, and locomotor activity [1]. The skeletal muscle atrophy in response to disuse occurs during bed rest or spaceflight associated with the loss of muscle mass and the decline in muscle strength and power [2], muscular activity and cross-sectional area of muscle fiber [3]. The soleus muscle (SOL), which is predominantly composed of slow twitch fibers, is a postural muscle and more sensitive to disuse than fast-twitch muscles (extensor digitorum longus) and hybrid muscles (gastrocnemius) [4-6]. Disuse atrophy results in reduced protein content and a net loss of contractile proteins [7]. A proteomic study on rat soleus muscle after 3-week hindlimb unloading indicates that proteomic responses to disuse had a 0.2 - to 0.6 -fold decrease in the protein levels of myosin light chain 1 (MLC1), $\alpha$-actin, tropomyosin $\beta$-chain, and troponins $\mathrm{T}$ [8]. Moreover, a number of results obtained showed that atrophic changes during a space flight or under head-down bed-rest are accompanied by decrease of total muscle protein [9] and myofibril proteins degradation [10]. Accordingly, disuse atrophy is supposed to be the result of shift of protein synthesis/proteolysis balance towards protein degradation increase [11], although many details remain unknown.

However, the skeletal muscle of hibernators appears to deviate from significant atrophy even after experiencing from extended disuse over three to four months, even six months in the cold North. It has been demonstrated that the muscle-fiber number and cross-sectional area were unchanged in gastrocnemius and biceps femoris of hibernating black bears (Ursus americanus), while protein concentration decreased in both muscles during the hibernation period, suggesting only marginal muscle atrophy [12]. In addition, it has also been reported that hibernating ground squirrels (Citellus undulatus and Spermophilus dauricus) have an evolutionarily determined adaptive mechanism of preservation or increase of slow fibers ratio [13], as the most economic and energetically advantageous, with proteins typical of them, whereas hindlimb unloading of non-hibernators (such as mouse) leads to activation of proteolysis and destruction of myofibrillar integrity, which contributes to considerable atrophy of soleus fibers [14]. Our previous research showed that SOL muscle mass to total body mass ratios (mg/g) were significantly higher in hibernating Daurian ground squirrels compared with that of rats after 14 days of hindlimb suspension, mirroring an effect protecting against disuse atrophy [15]. Daurian ground squirrels (Spermophilus dauricus) are obligatory hibernating mammals. They are found across a wide range of latitudes, from steppe and semi-desert and other arid regions of northern China. Hibernation of Daurian ground squirrels provides a useful model to study mechanisms that increases skeletal muscle resilience against atrophy and dysfunction after extended periods of disuse [16].

The study on measuring skeletal muscle protein metabolism of bears suggests that protein synthesis and breakdown are both lower in winter compared to summer but are equal during both early and late hibernation periods, indicating that bears are in protein balance during hibernation [17]. Which plays a predominant role in the maintenance of skeletal muscle homeostasis involved in the mechanism of protecting from muscle atrophy during prolonged disuse in hibernation, the increase of protein synthesis or the decrease of protein degradation? It is noteworthy that the protein biosynthesis category by overexpressed genes exhibits a highly significant enrichment in skeletal muscle of hibernating black bears (Ursus americanus) [18]. However, serum- and glucocorticoid-inducible kinase 1 (SGK1) can regulate muscle mass maintenance via downregulation of proteolysis and autophagy during hibernation in 13-lined ground squirrels (Ictidomys tridecemlineatus) [19], which is consistent with our previous report demonstrating that the inhibition of calpain activity and consequently calpain-mediated protein degradation by highly elevated calpastatin protein expression levels may be an important mechanism for preventing muscle protein loss during hibernation [15]. Recently, our group reported that the stable expression of atrogin-1 and MuRF1 may facilitate to prevent SOL [20] and extensor digitorum longus [21] muscle atrophy during hibernation. Although more and more regulatory factors involved in the protein metabolism of skeletal muscle during hibernation were found, the detailed mechanisms of protein synthesis and breakdown in hibernation are far from being elucidated.

To our knowledge we yet understand little about myofibrillar contents and relevant synthesis and proteolytic proteins in soleus muscle of hibernating ground squirrels. It is likely that novel mechanisms are involved but are not yet identified. Proteomics approaches are effective at identifying new protein signaling networks. Herein, we conducted isobaric tags for relative and absolute quantitation (iTRAQ) proteomics experiments in order to discover the hibernation-specific skeletal muscle proteomic changes. The aims of the present study were (1) to identify differentially expressed proteins among pre-hibernation, 60-d-hibernation and post-hibernation Daurian ground squirrels; (2) to explore the myofibrillar protein metabolism mechanism underlying the observed anti-atrophy effects in SOL of hibernating ground squirrels with the special ecological environment physiological adaptation. 


\section{Methods}

\section{Acquisition of animals}

Acquisition and use of animals were approved by the Laboratory Animal Care Committee of the China Ministry of Health. As described previously by our laboratory [15], nine male Daurian ground squirrels were obtained from the Weinan region in the Shaanxi province of China and kept in the laboratory for three to four months after collection for acclimation purposes before they were split into groups. The animal colony room was maintained at a temperature range of $18-20{ }^{\circ} \mathrm{C}$, and lighting was changed daily to coincide with local sunrise and sunset. Animals were given wood chips. Squirrels were provided with water and rodent food blocks, and supplemented with fresh fruit and vegetables. In November, three groups were placed in a cold room hibernaculum at $\left(4-6{ }^{\circ} \mathrm{C}\right)(2 \mathrm{~L}: 22 \mathrm{D}$ dark). The dates of entering torpor were determined by putting sawdust on the back of each animal. Daily observations were made during the experimental period. Animals were matched for body mass and were randomly assigned to 3 groups: prehibernation: Control (no hibernation) animals investigated in late-autumn, about 30-40 d before hibernation; 60-d hibernation: Animals after two months of hibernation; post-hibernation: Animals two days after arousal from $112 \pm 14$ days of hibernation, with the SOL muscle collected $48 \mathrm{~h}$ after arousal. We used 3 animals per time point, then the 3 samples combined before iTRAQ labeling. In order to minimize the impact of individual differences and avoid interference from other factors, we choose animals with the same sex (male), the similar body $(350 \pm 20 \mathrm{~g})$ weight and frequency of inter-bout arousal in hibernation for one sample. The SOL muscle was in a disuse state in the hibernation, but was not in a disuse state in the pre-hibernation and post-hibernation group.

\section{Immunofluorescent analysis}

Ten- $\mu \mathrm{m}$ thick frozen muscle cross-sections were cut from the mid-belly of muscle at $-20{ }^{\circ} \mathrm{C}$ with a cryostat (Leica, Wetzlar, CM1850, Germany), and stored at $-80^{\circ}$ Cfor further staining. Immunofluorescent analysis was used to determine muscle fiber cross-sectional area. After fixing in $4 \%$ paraformaldehyde for $30 \mathrm{~min}$, sections were permeabilized in $0.1 \%$ Triton X-100/PBS for 30 min, blocked with $1 \%$ bovine serum albumin (BSA) in PBS for $60 \mathrm{~min}$ at room temperature, and then incubated with the anti-laminin rabbit polyclonal antibody solution (1:50; Santa Cruz, CA, USA) at $4{ }^{\circ} \mathrm{C}$ overnight. The slides were rinsed twice in PBS and incubated with TRITC-labeled goat anti-rabbit IgG for $60 \mathrm{~min}$ and also counterstained with DAPI $(0.5 \mu \mathrm{g} / \mathrm{ml})$ for $30 \mathrm{~min}$. Images were visualized using a confocal laser scanning microscope (Olympus, Osaka, Japan) at an objective magnification of $40 \times$ and were counted on at least 3 different fields or 600 cells of each sample.

\section{Muscle collection and protein preparation}

All animal procedures were approved by the Northwest University Ethics Committee. Unless otherwise indicated, all chemicals were purchased from Sigma-Aldrich. Animals were anesthetized with $90 \mathrm{mg} / \mathrm{kg}$ sodium pentobarbital i.p. After SOL muscles in ground squirrels were excised from both legs, body mass and wet mass of SOL were recorded. At the end of surgical intervention, the animals were sacrificed by an overdose injection of sodium pentobarbital. Then the SOL muscle samples were ground into powder in liquid nitrogen, extracted with Lysis buffer (7 M Urea, $2 \mathrm{M}$ Thiourea, $4 \%$ CHAPS, $40 \mathrm{mM}$ Tris- $\mathrm{HCl}, \mathrm{pH}$ 8.5) containing $1 \mathrm{mM}$ PMSF and $2 \mathrm{mM}$ EDTA. After $5 \mathrm{~min}, 10 \mathrm{mM}$ DTT (final concentration) was added to the samples. The suspension was sonicated at $200 \mathrm{~W}$ for $15 \mathrm{~min}$ and then centrifuged at $4{ }^{\circ} \mathrm{C}, 30,000 \mathrm{~g}$ for $15 \mathrm{~min}$. The supernatant was mixed well with $5 \times$ volume of chilled acetone containing $10 \%$ (v/v) TCA and incubated at $-20{ }^{\circ} \mathrm{C}$ overnight. After centrifugation at $4{ }^{\circ} \mathrm{C}, 30,000 \mathrm{~g}$, the supernatant was discarded. The precipitate was washed with chilled acetone three times. The pellet was air-dried and dissolved in Lysis buffer (7 M urea, $2 \mathrm{M}$ thiourea, 4 \% NP40, $20 \mathrm{mM}$ Tris- $\mathrm{HCl}, \mathrm{pH} 8.0-8.5)$. The suspension was sonicated at $200 \mathrm{~W}$ for $15 \mathrm{~min}$ and centrifuged at $4{ }^{\circ} \mathrm{C}, 30,000 \mathrm{~g}$ for $15 \mathrm{~min}$. The supernatant was transferred to another tube. To reduce disulfide bonds in proteins of the supernatant, $10 \mathrm{mM}$ DTT (final concentration) was added and incubated at $56{ }^{\circ} \mathrm{C}$ for $1 \mathrm{~h}$. Subsequently, $55 \mathrm{mM}$ IAM (final concentration) was added to block the cysteines, incubated for $1 \mathrm{~h}$ in the darkroom. The supernatant was mixed well with $5 \times$ volume of chilled acetone for $2 \mathrm{~h}$ at $-20{ }^{\circ} \mathrm{C}$ to precipitate proteins. After centrifugation at $4{ }^{\circ} \mathrm{C}, 30,000 \mathrm{~g}$, the supernatant was discarded, and the pellet was air-dried for $5 \mathrm{~min}$, dissolved in $500 \mu \mathrm{L} 0.5 \mathrm{M}$ TEAB (Applied Biosystems, Milan, Italy), and sonicated at $200 \mathrm{~W}$ for $15 \mathrm{~min}$. Finally, samples were centrifuged at $4{ }^{\circ} \mathrm{C}, 30,000 \mathrm{~g}$ for $15 \mathrm{~min}$. The supernatant was transferred to a new tube and kept at $-80{ }^{\circ} \mathrm{C}$ for further analysis.

\section{iTRAQ Labeling and SCX fractionation}

iTRAQ analysis was implemented at Beijing Genomics Institute (BGI, Shenzhen, China). Total protein $(100 \mu \mathrm{g})$ was taken out of each sample solution and then the protein was digested with Trypsin Gold (Promega, Madison, WI, USA) with the ratio of protein/trypsin $(30 / 1)$ at $37^{\circ} \mathrm{C}$ for $16 \mathrm{~h}$. After trypsin digestion, peptides were dried by vacuum centrifugation. Peptides were reconstituted in $0.5 \mathrm{M}$ TEAB and processed according to the manufacture's protocol for 8-plex iTRAQ reagent 
(Applied Biosystems). Briefly, one unit of iTRAQ reagent was thawed and reconstituted in $24 \mu \mathrm{L}$ isopropanol. SOL muscle samples were labeled with the iTRAQ tags as follow: pre-hibernation (tag 113), 60-day hibernation (tag 114) and post-hibernation (tag 116). The peptides were labeled with the isobaric tags, incubated at room temperature for $2 \mathrm{~h}$. The labeled peptide mixtures were then pooled and dried by vacuum centrifugation.

SCX chromatography was performed with a LC-20AB HPLC Pump system (Shimadzu, Kyoto, Japan). The iTRAQ-labeled peptide mixtures were reconstituted with $4 \mathrm{~mL}$ buffer A ( $25 \mathrm{mM} \mathrm{NaH}_{2} \mathrm{PO}_{4}$ in $\left.25 \% \mathrm{ACN}, \mathrm{pH} 2.7\right)$ and loaded onto a $4.6 \times 250 \mathrm{~mm}$ Ultremex SCX column containing $5-\mu \mathrm{m}$ particles (Phenomenex). The peptides were eluted at a flow rate of $1 \mathrm{~mL} / \mathrm{min}$ with a gradient of buffer A for $10 \mathrm{~min}, 5-60 \%$ buffer B (25 mM $\mathrm{NaH}_{2} \mathrm{PO}_{4}, 1 \mathrm{M} \mathrm{KCl}$ in $25 \% \mathrm{ACN}, \mathrm{pH} 2.7$ ) for $27 \mathrm{~min}$, 60-100 \% buffer B for $1 \mathrm{~min}$. The system was then maintained at $100 \%$ buffer B for 1 min before equilibrating with buffer A for $10 \mathrm{~min}$ prior to the next injection. Elution was monitored by measuring the absorbance at $214 \mathrm{~nm}$, and fractions were collected every $1 \mathrm{~min}$. The eluted peptides were pooled into 20 fractions, desalted with a Strata X C18 column (Phenomenex) and vacuum-dried.

\section{LC-ESI-MS/MS analysis based on Triple TOF 5600}

Each fraction was resuspended in buffer A $(5 \% \mathrm{ACN}$, $0.1 \% \mathrm{FA})$ and centrifuged at $20,000 \mathrm{~g}$ for $10 \mathrm{~min}$, the final concentration of peptide was about $0.5 \mu \mathrm{g} / \mu \mathrm{L}$ on average. $10 \mu \mathrm{L}$ supernatant was loaded on a LC-20 AD nano HPLC(Shimadzu, Kyoto, Japan) by the autosampler onto a $2 \mathrm{~cm}$ C18 trap column. Then, the peptides were eluted onto a $10 \mathrm{~cm}$ analytical C18 column (inner diameter $75 \mu \mathrm{m})$ packed in-house. The samples were loaded at $8 \mu \mathrm{L} / \mathrm{min}$ for $4 \mathrm{~min}$, then the $35 \mathrm{~min}$ gradient was run at $300 \mathrm{~nL} / \mathrm{min}$ starting from 2 to $35 \%$ buffer B (95\% $\mathrm{ACN}, 0.1 \% \mathrm{FA}$ ), followed by $5 \mathrm{~min}$ linear gradient to $60 \%$, then followed by 2 min linear gradient to $80 \%$, and maintenance at $80 \%$ buffer B for $4 \mathrm{~min}$, and finally return to $5 \%$ in $1 \mathrm{~min}$. Data acquisition was performed with a Triple TOF 5600 System (AB SCIEX, Concord, $\mathrm{ON}$ ) fitted with a Nanospray IIIsource (AB SCIEX, Concord, $\mathrm{ON}$ ) and a pulled quartz tip as the emitter (New Objectives, Woburn, MA). Data was acquired using an ion spray voltage of $2.5 \mathrm{kV}$, curtain gas of $30 \mathrm{psi}$, nebulizer gas of $15 \mathrm{psi}$, and an interface heater temperature of $150{ }^{\circ} \mathrm{C}$. The MS was operated with a RP of greater than or equal to 30,000 FWHM for TOF MS scans. For IDA, survey scans were acquired in $250 \mathrm{~ms}$ and as many as 30 product ion scans were collected if exceeding a threshold of 120 counts per second (counts/ s) and with a $2+$ to $5+$ charge-state. Total cycle time was fixed to $3.3 \mathrm{~s}$. Q2 transmission window was $100 \mathrm{Da}$ for
$100 \%$. Four time bins were summed for each scan at a pulser frequency value of $11 \mathrm{kHz}$ through monitoring of the $40 \mathrm{GHz}$ multichannel TDC detector with four-anode channel detect ion. A sweeping collision energy setting of $35 \pm 5 \mathrm{eV}$ coupled with iTRAQ adjust rolling collision energy was applied to all precursor ions for collision induced dissociation. Dynamic exclusion was set for $1 / 2$ of peak width $(15 \mathrm{~s})$, and then the precursor was refreshed off the exclusion list.

\section{Data analysis}

Raw data files acquired from the Orbitrap were converted into MGF files using Proteome Discoverer 1.2 (PD 1.2, Thermo), [5600 msconverter] and the MGF file were searched. Proteins identification was performed by using Mascot search engine (Matrix Science, London, UK, version 2.3.02) against database containing 28,942 sequences (up to date 2014-3-11). For protein identification, a mass tolerance of $0.05 \mathrm{Da}(\mathrm{ppm})$ was permitted for intact peptide masses and 0.1 Da for fragmented ions, with allowance for one missed cleavages in the trypsin digests. Gln- > pyro-Glu (N-term Q), Oxidation $(\mathrm{M})$, Deamidated (NQ) as the potential variable modifications, and Carbamidomethyl (C), iTRAQ8plex (Nterm), iTRAQ8plex (K) as fixed modifications. The charge states of peptides were set to +2 and +3 . Specifically, an automatic decoy data base search was performed in Mascot by choosing the decoy checkbox in which a random sequence of database is generated and tested for raw spectra as well as the real database. To reduce the probability of false peptide identification, only peptides with significance scores $(\geq 20)$ at the $99 \%$ confidence interval by a Mascot probability analysis greater than " $i$ dentity" were counted as identified. And each confident protein identification involves at least one unique peptide. For protein quantitation, it was required that a protein contains at least two unique peptides. The quantitative protein ratios were weighted and normalized by the median ratio in Mascot. We only used ratios with pvalues $<0.05$, and only fold changes of $>1.2$ was considered as significant.

\section{Function method description}

Functional annotations of the proteins were conducted using Blast2GO program against the non-redundant protein database (NR; NCBI). The KEGG database (http://www.genome.jp/kegg/) and the COG database (http://www.ncbi.nlm.nih.gov/COG/) were used to classify and group these identified proteins.

\section{Pathway analysis}

KEGG PATHWAY is a database resource and a collection of manually drawn pathway maps [22, 23] representing our knowledge on the molecular interaction and 
reaction networks between the identified differentially expressed proteins in 60-d hibernation and posthibernation ground squirrels groups compared to the pre-hibernation groups. Molecules are represented as nodes, and the biological relationship between two nodesis represented as an edge (line).

\section{Western blotting}

To confirm the reliability of iTRAQ based quantitative analysis, protein samples used for iTRAQ were further examined by western blot which were undertaken as previously described [24]. Briefly, total protein was extracted from the SOL muscle of ground squirrels and solubilized in a sample buffer (100 mM Tris, pH 6.8, $5 \%$ 2 - $\beta$-mercaptoethanol, $5 \%$ glycerol, $4 \%$ SDS, and bromophenol blue), with muscle protein extracts resolved by SDS-PAGE using Laemmli gels $(10 \%$ gel with an acrylamide/bisacrylamide ratio of $37.5: 1$ for EEF-2; and $12 \%$ gel with an acrylamide/bisacrylamide ratio of $29: 1$ for RPS8, proteasome 20S $\alpha 5$, CAPNS1, actin, and troponin C. After electrophoresis, the proteins were electrically transferred to PVDF membranes $(0.45 \mu \mathrm{m}$ pore size) using a Bio-Rad semi-dry transfer apparatus. The blotted membranes were blocked with $1 \%$ BSA in Tris-buffered saline (TBS; $150 \mathrm{mM} \mathrm{NaCl}, 50 \mathrm{mM}$ Tris$\mathrm{HCl}, \mathrm{pH} 7.5)$ and incubated with rabbit anti-Proteasome $20 \mathrm{~S} \alpha 5$, rabbit anti-Actin, rabbit anti-Troponin $C$, rabbit anti-EEF2 and rabbit anti-RPS8 (1:1000, Abcam, Cambridge, MA, USA) and rabbit anti-CAPNS1 (1:1000, Sigma, St. Louis, MO, USA) in TBS containing $0.1 \%$ BSA at $4{ }^{\circ} \mathrm{C}$ overnight. After washing 3 times, the membranes were then incubated with HRP-conjugated anti-rabbit secondary antibodies (Pierce Chemical Co., Dallas, USA) for $1 \mathrm{~h}$ at room temperature. After another washing, immunoblots were visualized using enhanced chemiluminescence (ECL) reagents (Thermo, Rockford, USA.) according to the manufacturer's protocols. Quantification analysis of blots was performed with the $\mathrm{NIH}$ Image J software.

\section{Total protein breakdown in incubated muscles}

Rates of protein degradation was determined by the release of tyrosine in incubated soleus muscles as previously described [25]. As tyrosine is present in all proteins, its release reflects total protein breakdown. Briefly, the ground squirrels were anesthetized and the soleus muscles were gently dissected and excised with intact tendons. Immediately after weighing, muscles were secured with custom plastic clips at approximately resting length in order to better maintain their energy level and protein balance. Muscles were incubated for $30 \mathrm{~min}$ in oxygenated $\left(\mathrm{O}_{2}: \mathrm{CO}_{2}=95: 5\right)$ Krebs-Henseleit buffer (pH 7.4) containing $5 \mathrm{mM}$ glucose and $0.15 \mathrm{mM}$ pyruvate. After preincubation, one muscle was homogenized in $3 \%$ perchloric acid for determination of tissue levels of free tyrosine. The contralateral muscle was then blotted and transferred to a new incubation well containing $3 \mathrm{~mL}$ Krebs-Henseleit/glucose/pyruvate buffer and $0.5 \mathrm{mM}$ cycloheximide, which inhibited reincorporation of amino acids by protein synthesis. Three hours after incubation, muscles were removed, blotted dry, and frozen in liquid nitrogen. Then the muscle and medium concentrations of free tyrosine were measured by high performance liquid chromatography (Agilent HPLC system, Column: Agilent TC-C18, $5 \mu \mathrm{m}, 4.6 \times 250 \mathrm{~mm}$, USA), which was equipped with a binary pump (Agilent G1312A) and a fluorescence detector (Agilent G1321A). Rates of protein degradation are given as nmol tyrosine per gram of muscle wet weight per $3 \mathrm{~h}$.

\section{Statistical analyses}

A one-way ANOVA with Fisher's LSD post hoc test was used to determine group differences, and the ANOVA-Dunnett's T3 method was used when no homogeneity was detected. SPSS 19.0 was used for all statistical tests. Statistical significance was accepted for all tests at $P<0.05$.

\section{Results \\ Body weight, soleus muscle wet weight and muscle fiber cross-sectional area (CSA)}

There was a steady decline in mean body weight from $352 \pm 24 \mathrm{~g}$ in pre-hibernation to $263 \pm 8 \mathrm{~g}$ after 60 days of hibernation, and there was even a sharp body weight decrease to $222 \pm 11 \mathrm{~g}$ in post-hibernation. In other words, the ground squirrels lost 25 and $40 \%$ of the body weight after hibernation for 60 days and posthibernation, respectively (Fig. 1a). However, the SOL muscle wet weights were decreased slightly in $60-\mathrm{d}$ or post-hibernation ground squirrels in comparison with the pre-hibernation group (Fig. 1b). Meanwhile, the CSA of SOL muscle also showed no significant decrease in $60-\mathrm{d}$ or post-hibernation groups as compared with the pre-hibernation group (Fig. 1c and d).

\section{Proteomics analysis}

In the present study, an iTRAQ-based quantitative proteomics approach in combination with LC-ESI-MS/MS was applied to investigate differentially expressed proteins in the SOL of pre-hibernation, 60-d hibernation and post-hibernation ground squirrels. Proteomics analysis identified 11,897 peptides mapped to 2059 proteins. iTRAQ ratio of $>1.20$ and $<0.83(P$-value $<0.05)$ was used to define proteins that are significantly upregulated or down-regulated, respectively. With this filter, we identified 170 and 333 differentially regulated proteins in the $60-\mathrm{d}$ and post-hibernation groups relative to the pre-hibernation ground squirrels, respectively. 

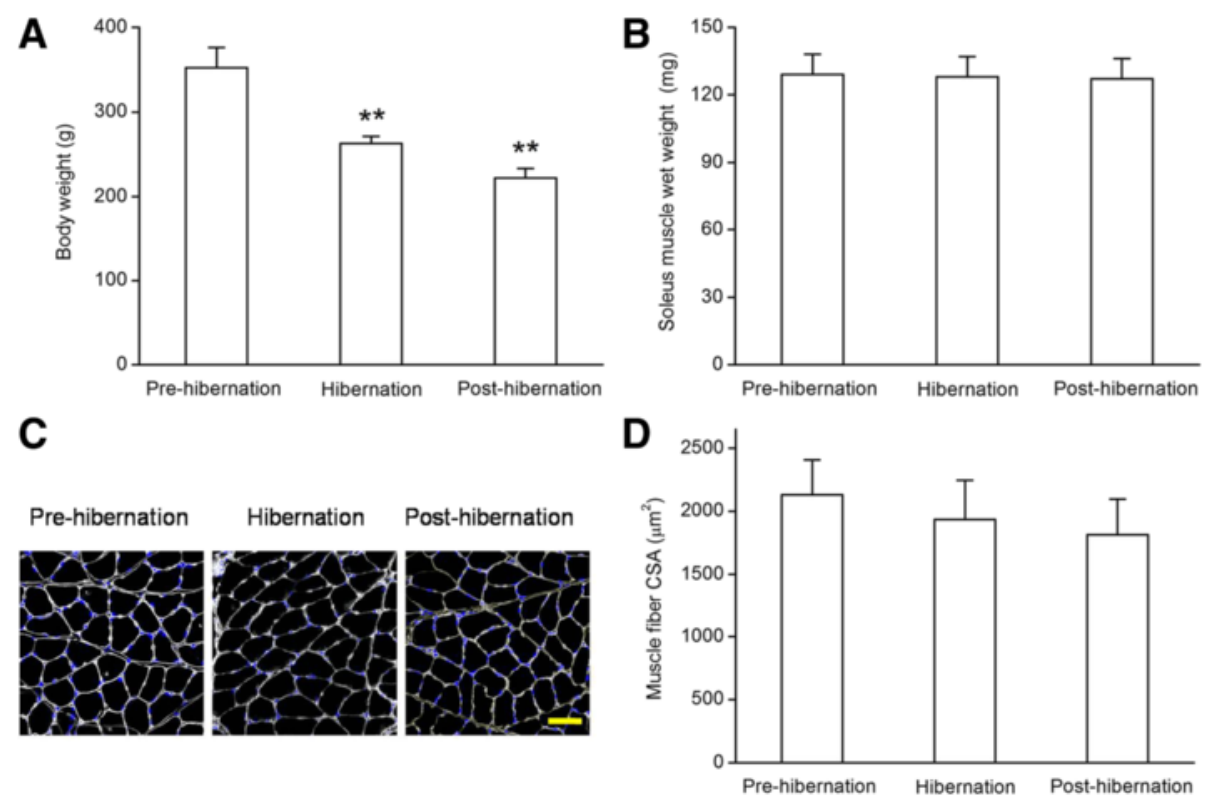

Fig. 1 Body weight (a) and soleus muscle wet weight (b) of Daurian ground squirrels in pre-hibernation, 60-d and post-hibernation groups. Representative images (c) and bar graph (d) showing the changes in cross-sectional area of soleus muscle from 3 groups. White represents the anti-laminin stain of interstitial tissue counterstained with DAPI (blue) for nuclei identifcation. Scale bar $=50 \mu \mathrm{m}$. Values are means \pm SEM, $n=6$ in each group. ${ }^{* *} P<0.01$ versus pre-hibernation group

Besides, 273 differentially regulated proteins were identified in the post-hibernation group compared to the $60-\mathrm{d}$ hibernation ground squirrels. These proteins were subjected to gene-ontology enrichment. Among the three groups, the differences between 60 -d hibernation and pre-hibernation were smaller (96 vs 248 up-regulated proteins and 74 vs 85 down-regulated proteins) as compared with the differences between post-hibernation and pre-hibernation ground squirrels. Moreover, 216 upregulated proteins and 57 down-regulated were identified in the post-hibernation group compared to the 60-d hibernation ground squirrels. Specifically, there were 248 up-regulated expressed proteins between posthibernation and pre-hibernation ground squirrels, almost one third of the total number (776) of differentially expressed proteins among three ground squirrels groups.

\section{Gene ontology (GO) classification of differentially expressed proteins}

To elucidate the biological significance of the 776 differentially modified proteins, we performed GO analysis and categorized these proteins according to their molecular function and biological process using the KEGG database (http://www.genome.jp/kegg/) and the COG database (http://www.ncbi.nlm.nih.gov/COG/). Of the 776 proteins, 123 were selected from these analyses and separated into 3 categories according to their molecular function: protein synthesis, protein proteolysis and structural constituent of muscle. Figure 2 showed the number of significantly $(P<0.05)$ differentially expressed proteins in the 3 categories. Proteins were annotated according to the gene ontology (GO) classification (Tables 1, 2 and 3).

\section{Pathway analysis}

Ribosomes are the sites of protein synthesis, the increased expression of these proteins may have improved protein synthesis in hibernating ground squirrels. Of the proteins identified by iTRAQ that were differentially expressed between 60-d hibernation group and pre-

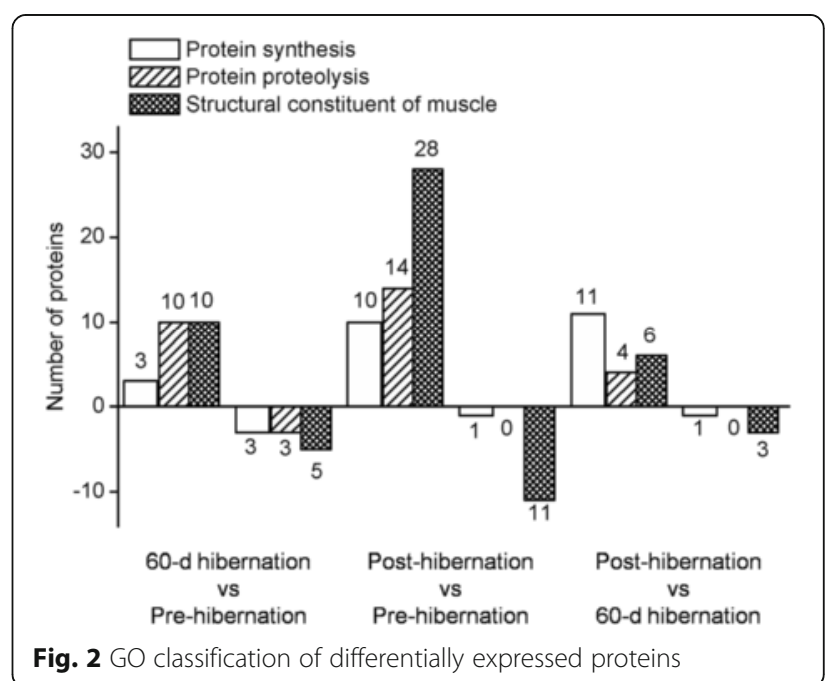


Table 1 Summary table showing significantly up-regulated or down-regulated proteins in SOL of Daurian ground squirrels identified by ITRAQ

\begin{tabular}{|c|c|c|c|c|c|c|c|c|c|c|}
\hline \multirow[t]{2}{*}{ Acc no. (NCBI) } & \multirow[t]{2}{*}{ Prot name [lctidomys tridecemlineatus] } & \multirow[t]{2}{*}{$\begin{array}{l}\text { MW } \\
(\mathrm{Da})\end{array}$} & \multirow[t]{2}{*}{ Peptide } & \multirow[t]{2}{*}{ Score } & \multicolumn{2}{|c|}{$\begin{array}{l}60-d \text { hibernation } \\
\text { vs pre-hibernation }\end{array}$} & \multicolumn{2}{|c|}{$\begin{array}{l}\text { Post-hibernation vs } \\
\text { pre-hibernation }\end{array}$} & \multicolumn{2}{|c|}{$\begin{array}{l}\text { Post-hibernation } \\
\text { vs } 60 \text {-hibernation }\end{array}$} \\
\hline & & & & & Fold change & Sig & Fold change & Sig & Fold change & Sig \\
\hline \multicolumn{11}{|c|}{ Up-regulated proteins } \\
\hline gi|532099039 & elongation factor 1-beta isoform $\times 2$ & 32189 & 6 & 175 & 1.348 & * & 1.202 & * & & \\
\hline gi|532060958 & 605 ribosomal protein L39-like & 9445 & 1 & 58 & 1.791 & * & & & & \\
\hline gi|532064086 & polyadenylate-binding protein 4 isoform $\mathrm{X} 1$ & 87231 & 7 & 188 & 1.508 & * & & & & \\
\hline gi|532076481 & ATP-dependent RNA helicase DDX3X & 60127 & 11 & 481 & & & 1.283 & * & & \\
\hline gi|532064280 & $40 S$ ribosomal protein $\$ 8$ & 34224 & 6 & 177 & & & 1.349 & * & & \\
\hline gi|532090722 & eukaryotic initiation factor 4A-II isoform X1 & 51896 & 9 & 769 & & & 1.232 & * & & \\
\hline gi|532100826 & $60 S$ ribosomal protein L38 isoform X2 & 13441 & 2 & 71 & & & 1.679 & * & & \\
\hline gi|532073691 & 605 ribosomal protein L30-like & 17542 & 2 & 66 & & & 1.366 & * & & \\
\hline gi|532092237 & 605 ribosomal protein L10-like isoform X1 & 32972 & 1 & 68 & & & 1.276 & * & 1.419 & * \\
\hline gi|532092821 & elongation factor 2 & 116340 & 23 & 1556 & & & 1.227 & * & & \\
\hline gi|532114042 & 605 acidic ribosomal protein $\mathrm{P} 2$ isoform $\mathrm{X} 3$ & 15038 & 5 & 699 & & & 1.455 & * & & \\
\hline gi|532060529 & elongation factor 1-delta isoform X4 & 37312 & 8 & 983 & & & 1.476 & * & 1.292 & * \\
\hline gi|532064519 & $60 S$ ribosomal protein L11 & 13027 & 1 & 53 & & & & & 1.329 & * \\
\hline gi|532085355 & 40 S ribosomal protein $\mathbf{S} 25$ & 22308 & 2 & 114 & & & & & 1.228 & * \\
\hline gi|532098257 & $60 S$ ribosomal protein $L 22$ & 14812 & 2 & 160 & & & & & 1.364 & * \\
\hline gi|532071999 & $60 S$ ribosomal protein $\mathrm{L} 23$ & 19837 & 5 & 246 & & & & & 1.345 & * \\
\hline gi|532082343 & $60 S$ ribosomal protein $L 27 a$ & 27522 & 2 & 86 & & & & & 1.214 & * \\
\hline gi|532110684 & $40 S$ ribosomal protein $\mathrm{S} 4, \mathrm{X}$ isoform & 38325 & 3 & 192 & & & & & 1.244 & * \\
\hline gi|532082140 & $40 S$ ribosomal protein $\mathrm{S} 13$ & 22992 & 4 & 72 & & & & & 1.238 & * \\
\hline gi|532094470 & $60 S$ ribosomal protein L26 & 24853 & 1 & 34 & & & & & 1.225 & * \\
\hline gi|532075928 & $40 \mathrm{~S}$ ribosomal protein $\mathrm{S15a}$ & 18594 & 3 & 117 & & & & & 1.223 & * \\
\hline \multicolumn{11}{|c|}{ Down-regulated proteins } \\
\hline gi|532085355 & 40 S ribosomal protein S25 & 22308 & 2 & 114 & 0.758 & * & & & & \\
\hline gi|532098257 & $60 S$ ribosomal protein L22 & 14812 & 2 & 160 & 0.723 & * & & & & \\
\hline gi|532083400 & $40 S$ ribosomal protein S7 & 33087 & 3 & 90 & 0.735 & * & & & & \\
\hline gi|532066199 & 605 ribosomal protein L10a & 25228 & 2 & 105 & & & 0.74 & * & & \\
\hline gi|532096351 & $28 \mathrm{~S}$ ribosomal protein $\mathrm{S} 25$ & 24779 & 1 & 51 & & & & & 0.588 & * \\
\hline
\end{tabular}

Acc no. (Accession number), Prot name (protein name), MW (Molecular mass), Peptide (number of peptides matched), Score (Mowse score), Sig $\left({ }^{*} P\right.$-value $<0.05$ was considered statistically significant)

hibernation group, 5 enriched in the ribosomal assembly pathways (60S ribosomal protein L39-like, 40S ribosomal protein S6, 40S ribosomal protein S25, 60S ribosomal protein L22, 40S ribosomal protein S7, Fig. 3), and 8 of the proteins that were differentially expressed between post-hibernation group and pre-hibernation group enriched in this category (60S ribosomal protein L30like, $60 \mathrm{~S}$ acidic ribosomal protein $\mathrm{P} 2$ isoform X3, 60S ribosomal protein L10a, 40S ribosomal protein S13, $60 \mathrm{~S}$ ribosomal protein L10-like isoform X1, ubiquitin-60S ribosomal protein L40-like, $40 \mathrm{~S}$ ribosomal protein S8, 60 S ribosomal protein L38 isoform X2, Fig. 4). Meanwhile, 12 up-regulated proteins were enriched in the ribosomal assembly pathways between post-hibernation group and 60-d hibernation group (60S ribosomal protein L23, 60S ribosomal protein L26, 40S ribosomal protein S4, 60S ribosomal protein L11, 40S ribosomal protein S15a, 60S ribosomal protein L27a, 60S acidic ribosomal protein $\mathrm{P} 2$ isoform $\mathrm{X} 3$, 40S ribosomal protein $\mathrm{S} 13,60 \mathrm{~S}$ ribosomal protein L10-like isoform X1, 40S ribosomal protein S25, 60S ribosomal protein L22, 40S ribosomal protein S7, Fig. 5).

Numerous proteins were also involved in protein degradation. Proteasome is a multicatalytic proteinase complex with a highly ordered ring-shaped $20 \mathrm{~S}$ core structure and distributed throughout eukaryotic cells at a high concentration and cleave peptides in an ATPdependent process [26]. We found that 8 up-regulated 
Table 2 Summary table showing significantly up-regulated or down-regulated proteins with protein proteolysis function in SOL of Daurian ground squirrels identified by iTRAQ

\begin{tabular}{|c|c|c|c|c|c|c|c|c|c|c|}
\hline \multirow[t]{2}{*}{ Acc no. (NCBI) } & \multirow[t]{2}{*}{ Prot name [Ictidomys tridecemlineatus] } & \multirow[t]{2}{*}{$\begin{array}{l}\text { MW } \\
(\mathrm{Da})\end{array}$} & \multirow[t]{2}{*}{ Peptide } & \multirow{2}{*}{ Score } & \multicolumn{2}{|c|}{$\begin{array}{l}60-d \text { hibernation } \\
\text { vs pre-hibernation }\end{array}$} & \multicolumn{2}{|c|}{$\begin{array}{l}\text { Post-hibernation } \\
\text { vs pre-hibernation }\end{array}$} & \multicolumn{2}{|c|}{$\begin{array}{l}\text { Post-hibernation } \\
\text { vs } 60-d \text { hibernation }\end{array}$} \\
\hline & & & & & Fold change & Sig & Fold change & Sig & Fold change & Sig \\
\hline \multicolumn{11}{|c|}{ Up-regulated proteins } \\
\hline gi|532073955 & proteasome subunit alpha type- 6 & 28470 & 8 & 480 & 1.23 & * & 1.248 & * & & \\
\hline gi|532105099 & proteasome subunit alpha type- 5 & 30824 & 7 & 614 & 1.226 & * & 1.226 & * & & \\
\hline gi|59800155 & 265 protease regulatory subunit 10B & 53861 & 7 & 589 & 1.281 & * & 1.264 & * & & \\
\hline gi|532070252 & $\begin{array}{l}265 \text { proteasome non-ATPase regulatory } \\
\text { subunit } 5 \text { isoform X1 }\end{array}$ & 63125 & 2 & 46 & 1.517 & * & & & & \\
\hline gi|532091148 & $\begin{array}{l}265 \text { proteasome non-ATPase regulatory } \\
\text { subunit } 4\end{array}$ & 48541 & 5 & 133 & 1.488 & * & & & & \\
\hline gi|532103645 & proteasome subunit beta type- 6 isoform X1 & 27252 & 3 & 115 & 1.295 & * & & & & \\
\hline gi|532073989 & proteasome subunit alpha type-3 isoform $\mathrm{X} 1$ & 34727 & 5 & 462 & 1.209 & * & & & & \\
\hline gi|532066291 & cytosol aminopeptidase & 66612 & 11 & 731 & 1.202 & * & & & & \\
\hline gi|532101732 & $\begin{array}{l}26 \mathrm{~S} \text { protease regulatory subunit } 6 \mathrm{~B} \\
\text { isoform } \mathrm{X} 1\end{array}$ & 56577 & 4 & 375 & 1.246 & * & & & & \\
\hline gi|532088665 & $26 \mathrm{~S}$ protease regulatory subunit $6 \mathrm{~A}$ & 60713 & 9 & 638 & 1.32 & * & & & & \\
\hline gi|532080894 & calpastatin & 113441 & 7 & 179 & & & 1.226 & * & & \\
\hline gi|532073188 & endoplasmin & 117277 & 14 & 399 & & & 1.316 & * & & \\
\hline gi|532076563 & $\begin{array}{l}\text { ubiquitin-like modifier-activating enzyme } \\
1 \text { isoform } X 2\end{array}$ & 135211 & 19 & 1304 & & & 1.242 & * & & \\
\hline gi|532069763 & xaa-Pro aminopeptidase 1-like isoform X1 & 88255 & 5 & 128 & & & 1.485 & * & & \\
\hline gi|532062055 & proteasome subunit alpha type-4 & 37964 & 6 & 247 & & & 1.289 & * & & \\
\hline gi|532114683 & calpain small subunit 1 & 31666 & 4 & 257 & & & 1.301 & * & 1.488 & * \\
\hline gi|532105581 & $\begin{array}{l}\text { ubiquitin carboxyl-terminal hydrolase } 5 \\
\text { isoform X1 }\end{array}$ & 112519 & 10 & 369 & & & 1.221 & * & & \\
\hline gi|532082471 & acylamino-acid-releasing enzyme & 91596 & 7 & 160 & & & 1.567 & * & & \\
\hline gi|532088974 & prolyl endopeptidase & 95929 & 11 & 396 & & & 1.385 & * & & \\
\hline gi|532078165 & $\begin{array}{l}\text { ubiquitin carboxyl-terminal hydrolase } \\
\text { isozyme L3 }\end{array}$ & 30900 & 4 & 212 & & & 1.591 & * & 1.552 & * \\
\hline gi|532097874 & $\begin{array}{l}\text { ubiquitin fusion degradation protein } 1 \\
\text { homolog isoform } \mathrm{X} 1\end{array}$ & 41760 & 5 & 206 & & & 1.419 & * & & \\
\hline gi|532116708 & proteasome subunit beta type-1 & 30778 & 7 & 506 & & & & & 1.283 & * \\
\hline gi|532085114 & $\begin{array}{l}26 \mathrm{~S} \text { proteasome non-ATPase regulatory } \\
\text { subunit } 12 \text { isoform } X 1\end{array}$ & 66713 & 4 & 67 & & & & & 1.457 & * \\
\hline \multicolumn{11}{|c|}{ Down-regulated proteins } \\
\hline gi|532064840 & $\begin{array}{l}\text { ubiquinone biosynthesis protein COQ9, } \\
\text { mitochondrial }\end{array}$ & 38864 & 6 & 713 & 0.811 & * & & & & \\
\hline gi|532078642 & poly $(\mathrm{rC})$-binding protein 2 isoform $\mathrm{X} 1$ & 54651 & 5 & 470 & 0.732 & * & & & & \\
\hline gi|532086828 & cullin-5 & 114587 & 6 & 160 & 0.774 & * & & & & \\
\hline
\end{tabular}

Acc no. (Accession number), Prot name (protein name), MW (Molecular mass), Peptide (number of peptides matched), Score (Mowse score), Sig ${ }^{*} P$-value $<0.05$ was considered statistically significant)

proteins enriched in the proteasome pathway between $60-d$ hibernation group and pre-hibernation group (26S proteasome non-ATPase regulatory subunit 4, 26S protease regulatory subunit $10 \mathrm{~B}, 26 \mathrm{~S}$ protease regulatory subunit $6 \mathrm{~A}, 26 \mathrm{~S}$ protease regulatory subunit $6 \mathrm{~B}$ isoform $\mathrm{X} 1$, proteasome subunit alpha type-6, proteasome subunit alpha type-5, proteasome subunit alpha type-3 isoform $\mathrm{X} 1$, proteasome subunit beta type- 6 isoform $\mathrm{X} 1$, Fig. 6), 4 up-regulated proteins enriched in the proteasome pathway between post-hibernation group and pre-hibernation group (26S protease regulatory subunit $10 \mathrm{~B}$, proteasome subunit alpha type-6, proteasome subunit alpha type-4, proteasome subunit alpha type-5, Fig. 7), and 2 up-regulated proteins enriched in this 
Table 3 Summary table showing significantly up-regulated or down-regulated proteins of structural constituent of SOL muscle in Daurian ground squirrels identified by iTRAQ

\begin{tabular}{|c|c|c|c|c|c|c|c|c|c|c|}
\hline \multirow[t]{2}{*}{ Acc no. (NCBI) } & \multirow[t]{2}{*}{ Prot name [Ictidomys tridecemlineatus] } & \multirow[t]{2}{*}{$\begin{array}{l}\mathrm{MW} \\
(\mathrm{Da})\end{array}$} & \multirow[t]{2}{*}{ Peptide } & \multirow[t]{2}{*}{ Score } & \multicolumn{2}{|c|}{$\begin{array}{l}60-d \text { hibernation vs } \\
\text { pre-hibernation }\end{array}$} & \multicolumn{2}{|c|}{$\begin{array}{l}\text { Post-hibernation } \\
\text { vs pre-hibernation }\end{array}$} & \multicolumn{2}{|c|}{$\begin{array}{l}\text { Post-hibernation } \\
\text { vs } 60-d \text { hibernation }\end{array}$} \\
\hline & & & & & Fold change & Sig & Fold change & Sig & Fold change & Sig \\
\hline \multicolumn{11}{|c|}{ Up-regulated proteins } \\
\hline gi|532098453 & small muscular protein isoform $X 2$ & 12381 & 3 & 504 & 1.238 & * & 1.392 & * & & \\
\hline gi|532095619 & cofilin-1 & 26628 & 7 & 639 & 1.239 & * & 1.535 & * & & \\
\hline gi|532065022 & $\begin{array}{l}\text { tubulin polymerization-promoting protein } \\
\text { family member } 3\end{array}$ & 27600 & 2 & 147 & 1.607 & * & 1.481 & * & & \\
\hline gi|532085001 & myosin light chain 4 isoform $X 2$ & 27241 & 6 & 968 & 1.434 & * & 1.579 & * & & \\
\hline gi|532097561 & myelin basic protein & 44089 & 2 & 69 & 1.456 & * & & & & \\
\hline gi|532069819 & nebulin-related-anchoring protein & 245551 & 22 & 744 & 1.211 & * & & & & \\
\hline gi|532094579 & myosin-2 & 244418 & 102 & 66551 & 2.135 & $*$ & & & & \\
\hline gi|532087098 & PDZ and LIM domain protein 3 isoform $X 1$ & 45822 & 12 & 3700 & 1.304 & * & & & & \\
\hline gi|532062716 & troponin C & 22795 & 11 & 5693 & 1.358 & * & & & & \\
\hline gi|532080240 & vimentin & 54132 & 26 & 3859 & 1.211 & * & & & 1.828 & * \\
\hline gi|532089364 & myosin-binding protein $\mathrm{H}$ & 60653 & 11 & 835 & & & 1.696 & * & & \\
\hline gi|532081847 & zyxin & 72401 & 2 & 97 & & & 1.371 & * & & \\
\hline gi|532111896 & tubulin alpha-8 chain isoform $X_{1}$ & 60805 & 15 & 2177 & & & 1.355 & * & & \\
\hline gi|532063429 & $\begin{array}{l}\text { F-actin-capping protein subunit beta } \\
\text { isoform X2 }\end{array}$ & 36610 & 11 & 763 & & & 1.219 & * & & \\
\hline gi|532074211 & nidogen-2 isoform $\times 1$ & 165553 & 7 & 164 & & & 1.467 & * & & \\
\hline gi|532076843 & myozenin-3 & 30065 & 6 & 801 & & & 1.401 & * & & \\
\hline gi|532100104 & myosin light polypeptide 6 isoform $\mathrm{X} 1$ & 20132 & 8 & 2096 & & & 1.576 & * & & \\
\hline gi|532099239 & moesin-like & 87289 & 14 & 565 & & & 1.248 & * & & \\
\hline gi|532103138 & myosin regulatory light chain $12 \mathrm{~B}$ & 24691 & 6 & 374 & & & 1.771 & * & & \\
\hline gi|532081115 & talin-1 & 321070 & 21 & 790 & & & 1.288 & * & 1.302 & * \\
\hline gi|532088445 & $\begin{array}{l}\text { myosin regulatory light polypeptide } 9 \\
\text { isoform X1 }\end{array}$ & 24375 & 5 & 323 & & & 1.68 & * & & \\
\hline gi|532095126 & PDZ and LIM domain protein 7 & 60050 & 6 & 361 & & & 1.653 & * & & \\
\hline gi|532111349 & ankyrin-1 isoform X1 & 242338 & 33 & 1740 & & & 2.69 & * & & \\
\hline gi|532098546 & tubulin beta-5 chain-like & 46713 & 12 & 1245 & & & 1.367 & * & & \\
\hline gi|532061621 & annexin $\mathrm{A} 2$ & 49151 & 21 & 2021 & & & 1.502 & * & & \\
\hline gi|532068053 & myocilin & 59868 & 4 & 159 & & & 2.837 & * & & \\
\hline gi|532100974 & neurofilament heavy polypeptide & 158649 & 7 & 679 & & & 1.55 & * & & \\
\hline gi|532110489 & neurofilament medium polypeptide & 123496 & 7 & 571 & & & 1.677 & * & & \\
\hline gi|532089731 & tubulin alpha-4A chain & 56718 & 18 & 3110 & & & 1.396 & * & & \\
\hline gi|532089733 & tubulin alpha-1D chain-like & 57019 & 18 & 3316 & & & 2.103 & * & & \\
\hline gi|532063781 & protein 4.1 isoform $X 1$ & 120337 & 9 & 505 & & & 2.552 & * & & \\
\hline gi|532111734 & alpha-actinin-4 isoform X1 & 125310 & 18 & 2664 & & & 1.228 & * & & \\
\hline gi|532072736 & beta-adducin isoform $\mathrm{X}_{1}$ & 100809 & 3 & 84 & & & 1.759 & * & & \\
\hline gi|532083652 & tubulin beta-2A chain isoform $\mathrm{X} 1$ & 56576 & 21 & 2455 & & & 1.637 & * & 1.687 & * \\
\hline gi|532081219 & tropomodulin-1 & 49085 & 4 & 141 & & & & & 1.509 & * \\
\hline gi|532102653 & tubulin beta- $4 \mathrm{~B}$ chain isoform $\mathrm{X} 1$ & 55122 & 22 & 3594 & & & & & 1.25 & * \\
\hline gi|532062201 & fibrillin-1 & 340347 & 14 & 616 & & & & & 1.685 & * \\
\hline \multicolumn{11}{|c|}{ Down-regulated proteins } \\
\hline gi|532094519 & myosin-3 & 287961 & 49 & 33292 & 0.587 & * & 0.399 & * & 0.758 & * \\
\hline
\end{tabular}


Table 3 Summary table showing significantly up-regulated or down-regulated proteins of structural constituent of SOL muscle in Daurian ground squirrels identified by iTRAQ (Continued)

\begin{tabular}{|c|c|c|c|c|c|c|c|c|c|}
\hline gi|532085261 & transgelin isoform $X 2$ & 28099 & 11 & 691 & 0.784 & * & & & \\
\hline gi|532062201 & fibrillin-1 & 340347 & 14 & 616 & 0.534 & * & & & \\
\hline gi|532072041 & telethonin & 21240 & 8 & 817 & 0.811 & * & & & \\
\hline gi|532081219 & tropomodulin-1 & 49085 & 4 & 141 & 0.701 & * & & & \\
\hline gi|532103167 & actin & 48418 & 23 & 58752 & & 0.823 & * & 0.806 & * \\
\hline gi|532059726 & $\begin{array}{l}\text { xin actin-binding repeat-containing } \\
\text { protein 2-like }\end{array}$ & 476702 & 6 & 84 & & 0.774 & * & & \\
\hline gi|532069819 & nebulin-related-anchoring protein & 245551 & 22 & 744 & & 0.747 & * & & \\
\hline gi|532094510 & myosin-13 & 285781 & 37 & 26764 & & 0.478 & * & & \\
\hline gi|532077683 & kelch-like protein 41 & 85237 & 21 & 1666 & & 0.772 & * & & \\
\hline gi|532097391 & supervillin & 300575 & 12 & 302 & & 0.789 & * & & \\
\hline gi|532112765 & cytoplasmic dynein 1 heavy chain 1 & 620997 & 16 & 383 & & 0.807 & * & & \\
\hline gi|532113339 & obscurin, partial & 143269 & 19 & 783 & & 0.829 & * & & \\
\hline gi|532112836 & flotillin-1 & 56752 & 3 & 161 & & 0.806 & * & & \\
\hline gi|532062845 & filamin-B & 333949 & 10 & 1568 & & 0.743 & * & & \\
\hline gi|532094579 & myosin-2 & 244418 & 102 & 66551 & & & & 0.482 & * \\
\hline
\end{tabular}

Acc no. (Accession number), Prot name (protein name), MW (Molecular mass), Peptide (number of peptides matched), Score (Mowse score), Sig $(* P$-value $<0.05$ was considered statistically significant)

category between post-hibernation group and 60-d -hibernation group (26S proteasome non-ATPase regulatory subunit 12 isoform $\mathrm{X} 1$, proteasome subunit beta type-1, Fig. 8).

\section{Validation of the quantitative proteomic analysis by Western blotting}

Six proteins (EEF-2 and RPS8 associated with proterin synthesis, proteasome $20 \mathrm{~S} \alpha 5$ and CANPS1 associated with proterin proteolysis, actin and troponin $\mathrm{C}$ associated with myofibrillar contents) with the marked differences in expression determined by iTRAQ based quantitative analysis were selected to be verified by western blot analysis. As shown in Fig. 9, EEF-2, RPS8, proteasome $20 S \alpha 5$ and CNPNS1 were up-regulated $(P<0.05)$ in post-hibernation group as compared with prehibernation group, and proteasome $20 \mathrm{~S} \alpha 5$ and troponin $\mathrm{C}$ were up-regulated $(P<0.05)$ in hibernation group as compared with pre-hibernation group. However, actin was down-regulated in post-hibernation group as compared with pre-hibernation group $(P<0.05)$, which is consistent with the findings in iTRAQ analysis.

\section{Determination of protein proteolytic rate}

To determine whether the anti-muscle atrophy in the soleus of hibernating ground squirrels was a result of decreased proteolysis, we measured protein degradation by the release of the essential amino acid tyrosine. The rates of protein degradation decreased by $73 \%(P<$ 0.001 ) in hibernation group as compared with the prehibernation group. Although the proteolytic rate in post- hibernation squirrels increased approximately $200 \%$ $(P<0.001)$ as compared with the hibernation group, it was still $20 \%(P<0.01)$ lower than the prehibernation group (Fig. 10).

\section{Discussion}

In present study, we collected the SOL muscle from 60$\mathrm{d}$ and post-hibernation group with 2 months or more than 3 months of hibernation inactivity, which was long enough to cause significant atrophy in SOL muscle of non-hibernators [15]. The SOL muscle wet weight decreased less than the body weight in hibernating ground squirrels, which suggested an anti-atrophy effect during hibernation. Proteomic analysis was performed to investigated the protective proteins changes in soleus muscle of ground squirrels.

\section{Protective remodeling of myofibrillar proteins in preventing atrophy in SOL of Daurian ground squirrels during hibernation inactivity}

The cytoplasm of a myofiber contains a regular array of contractile units (sarcomeres) comprised of actincontaining thin filaments and myosin-containing thick filaments that, along with additional regulatory and structural proteins, are arranged longitudinally as myofibrils [27]. With iTRAQ approach, we identified myosin2 significantly up-regulated while myosin-3 significantly down-regulated in the 60-d hibernation group compared to the pre-hibernation group, meanwhile, myosin-13 significantly down-regulated in the post-hibernation group compared to the pre-hibernation group. Moreover, actin 


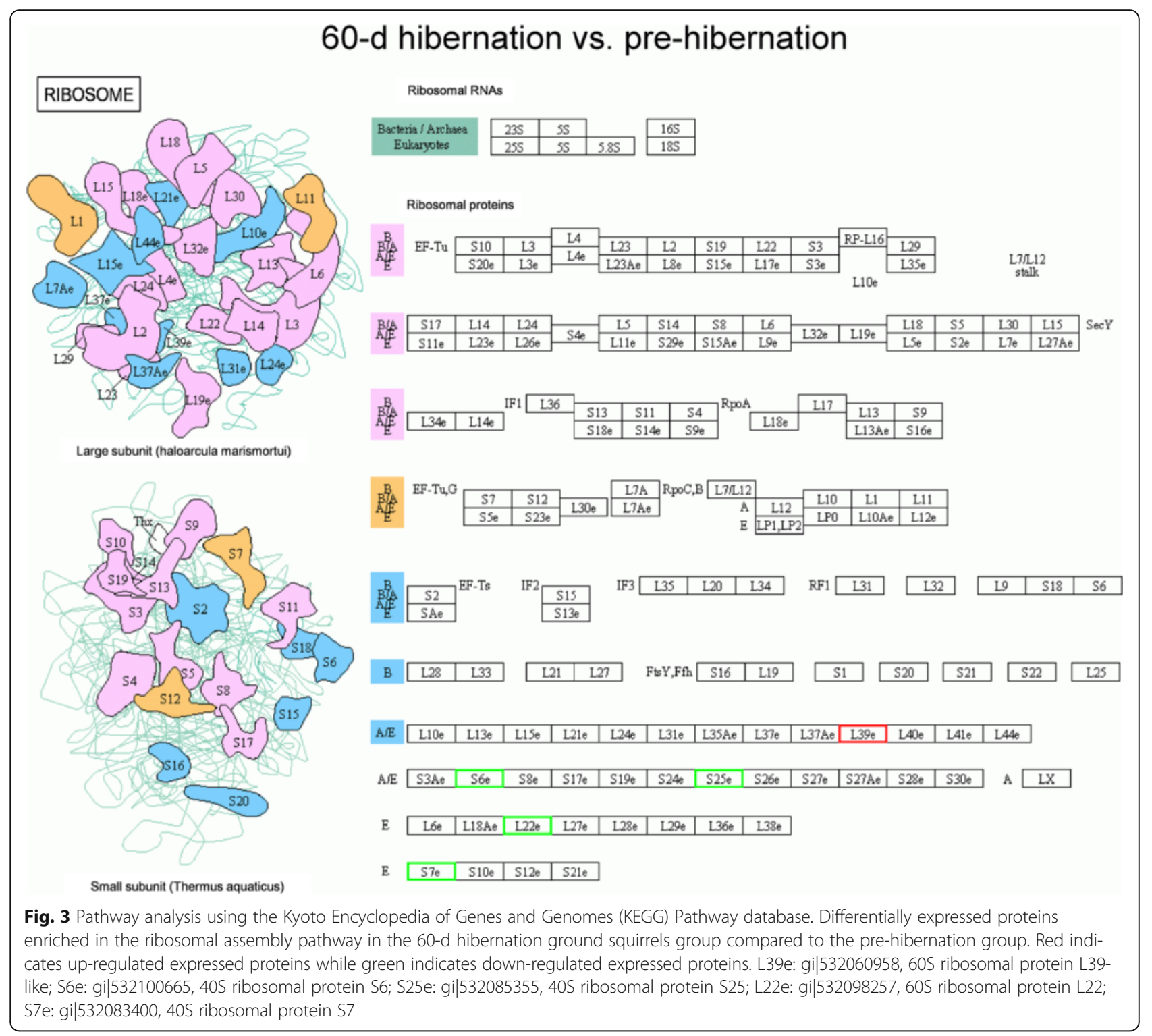

exhibited significantly down-regulated expression in the post-hibernation group compared to the pre-hibernation group (Table 3). The ratio of actin to myosin is one of the muscular atrophy hallmarks [28]. After 60-d hibernation inactivity, the ratio of actin/myosin filaments was likely to remain steady, however, a significant loss of myofibrillar proteins occured in post-hibernation group. Inconsistent with our results, the level of one isoform of actin was significantly higher $(P<0.05)$ in hibernation group than in summer active group in pectoral or biceps brachii muscles of the bat Murina leucogaster [28], which might be due to that the pectoral or biceps brachii muscles are involved in flight. But compared with the non-hibernator, lost of myofibrillar proteins in Daurian ground squirrel in hibernation is limited. For example, after 3 weeks of hindlimb unloading, levels of contractile proteins decreased by $40-70 \%$, and the ratio of actin/ myosin filaments decreased by $31 \%$ [8]. Reduction in muscle quality caused by alterations in myofilament contractile proteins (myosin and actin) may scale up from the molecular to the single fiber and tissue level to impact muscle performance [29]. Thus, up-regulation of myosin-2 is one of the most important mechanisms to maintain the integrity of the SOL muscle fiber in the 60$\mathrm{d}$ hibernation ground squirrels. Because the function of myosin-3 and myosin-13 in hibernation is unknown, the relationship between the decrease of these two myosin subtypes and skeletal muscle function is not clarified.

Other regulatory proteins also showed significant changes in hibernation. Troponin $\mathrm{C}$ was found significantly upregulated while tropomodulin-1 down-regulated in the 60$\mathrm{d}$ hibernation group compared to the pre-hibernation 


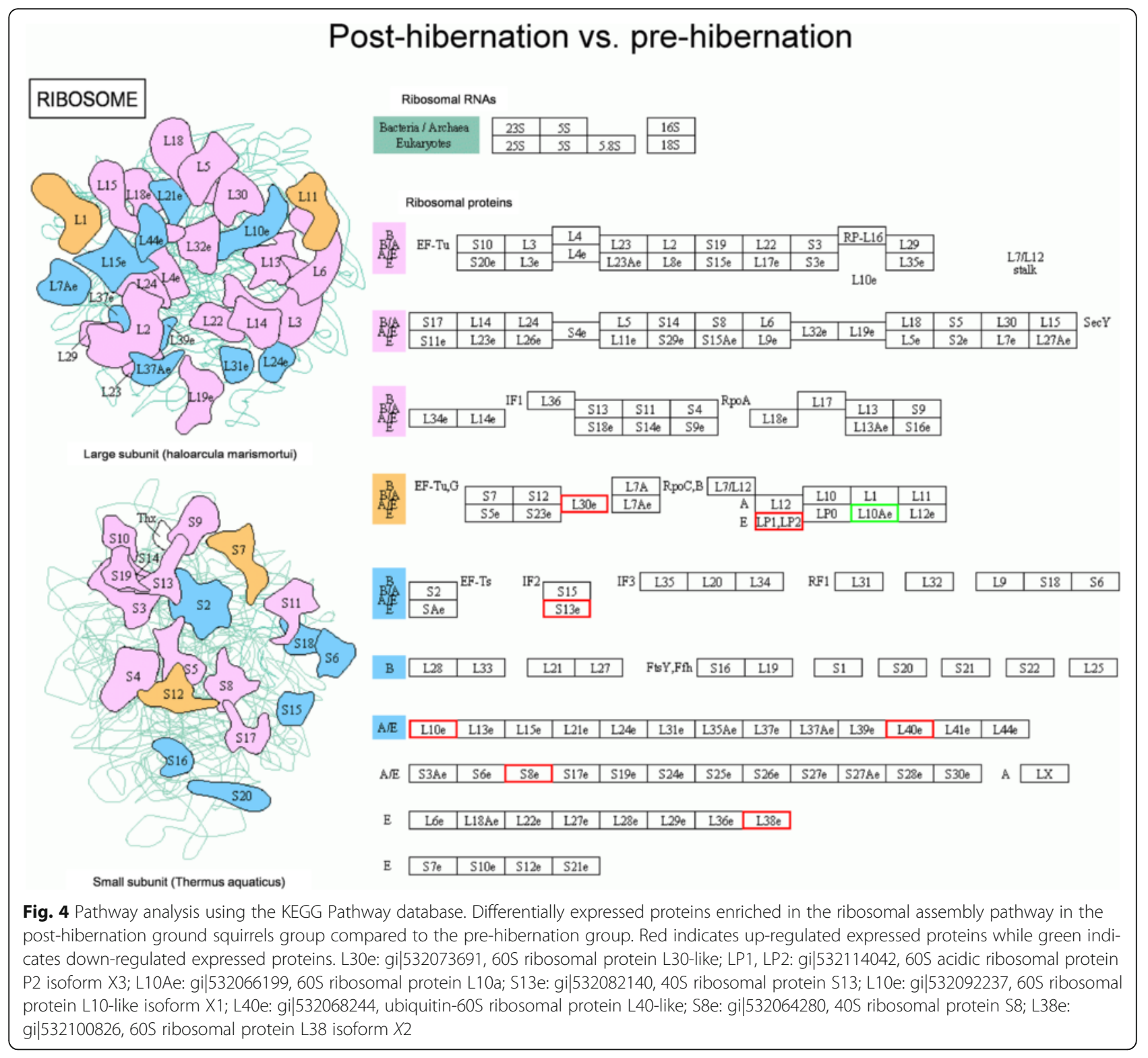

group. However, both troponin $\mathrm{C}$ and tropomodulin-1 was unaltered in the post-hibernation group. The binding of $\mathrm{Ca}^{2+}$ to troponin $\mathrm{C}$ induces a series of conformational changes in troponin complex and sarcomeric actin thin filament to activate cross bridge cycling between myosin and actin and muscle contraction [30]. Troponin $C$ increased by $59 \%$ in soleus of human bed rest study [31], which indicated that troponin $\mathrm{C}$ in SOL of hibernation changed similarly as in disuse. Another regulatory protein tropomodulin, which is the only protein known to cap the pointed end of actin filaments, plays an important role in actin-driven processes by controlling the addition and dissociation of actin subunits at filament ends [32]. Calpain-mediated proteolysis of tropomodulin isoforms leads to thin filament elongation in dystrophic skeletal muscle [33]. It appears reasonable to assume that the changes of tropomodulin might be an adaptive factor for inhibiting the contractile activity during hibernation. Moreover, over-expression of tropomodulin-1 in mouse hearts results in degenerating myofibrils [34]. Therefore, we assume that the downregulated tropomodulin-1 in 60-d hibernation might be a crucial component for regulating the length of actincontaining thin filament in soleus during hibernation.

Sarcomeric structural proteins such as $\alpha$-actinin, titin, tropomyosin and desmin were not detected proteomic variations in present study, which supported our previous findings that the stable expression of atrogin-1 and MuRF1 may facilitate to prevent SOL atrophy via controlling ubiquitination of muscle proteins during hibernation $[20,21]$. However, evidence showed that long-term disuse 


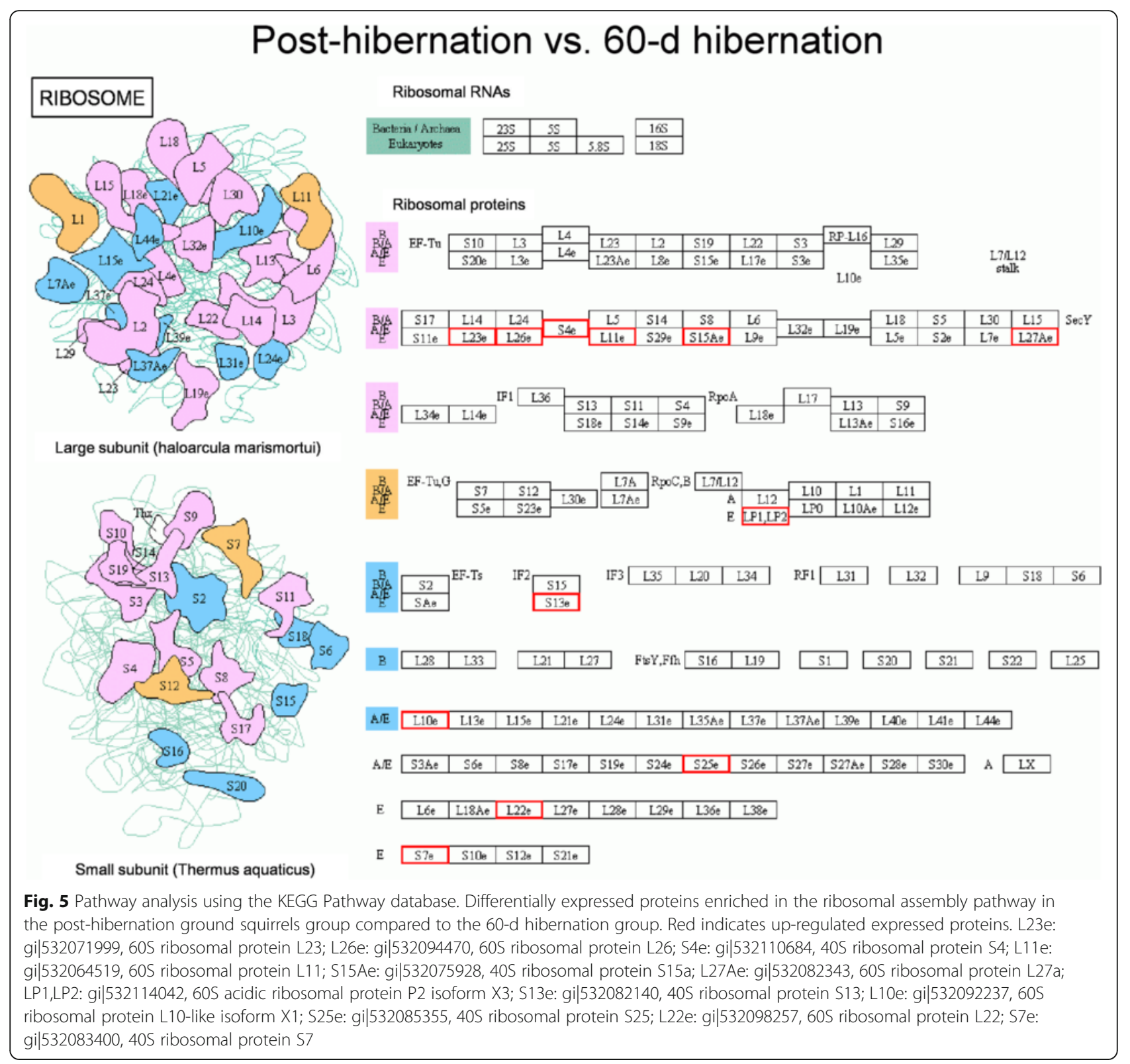

causes preferential loss of the giant sarcomere protein titin results in altered muscle function via abnormal sarcomeric organization [35]. The level of the T2 fragments of titin was observed decreased in the skeletal muscles of hibernating brown bear (Ursidae, Mammalia) [36]. Absence of $\alpha$ actinin-3 resulted in reduced atrophic response and altered adaptation to disuse [37]. Desmin and titin globally reduced in hibernating myocardium suggested a qualitative cardiomyocyte remodeling [38]. Obviously, homeostasis of most sarcomeric structural proteins is an important mechanism against disuse atrophy in ground squirrels.

In conclusion, these results suggested that myofibrillar protective remodeling marked by dysregulated contractile proteins (myosins and actin) and regulatory proteins (troponin and tropomodulin), and maintain of most sarcomeric structural proteins is a major factor in protecting atrophy in SOL of Daurian ground squirrels during hibernation.

The role of protein synthesis and proteolysis in preventing atrophy in SOL of Daurian ground squirrels during hibernation

Protein balance in skeletal muscles is a delicate interplay between protein synthesis and degradation [39]. High degradation and low synthesis of the proteins is known to cause significant loss of myofibrillar contents in most non-hibernators, including humans, prolonged disuse of skeletal muscle, as seen in bed rest, hindlimb suspension 

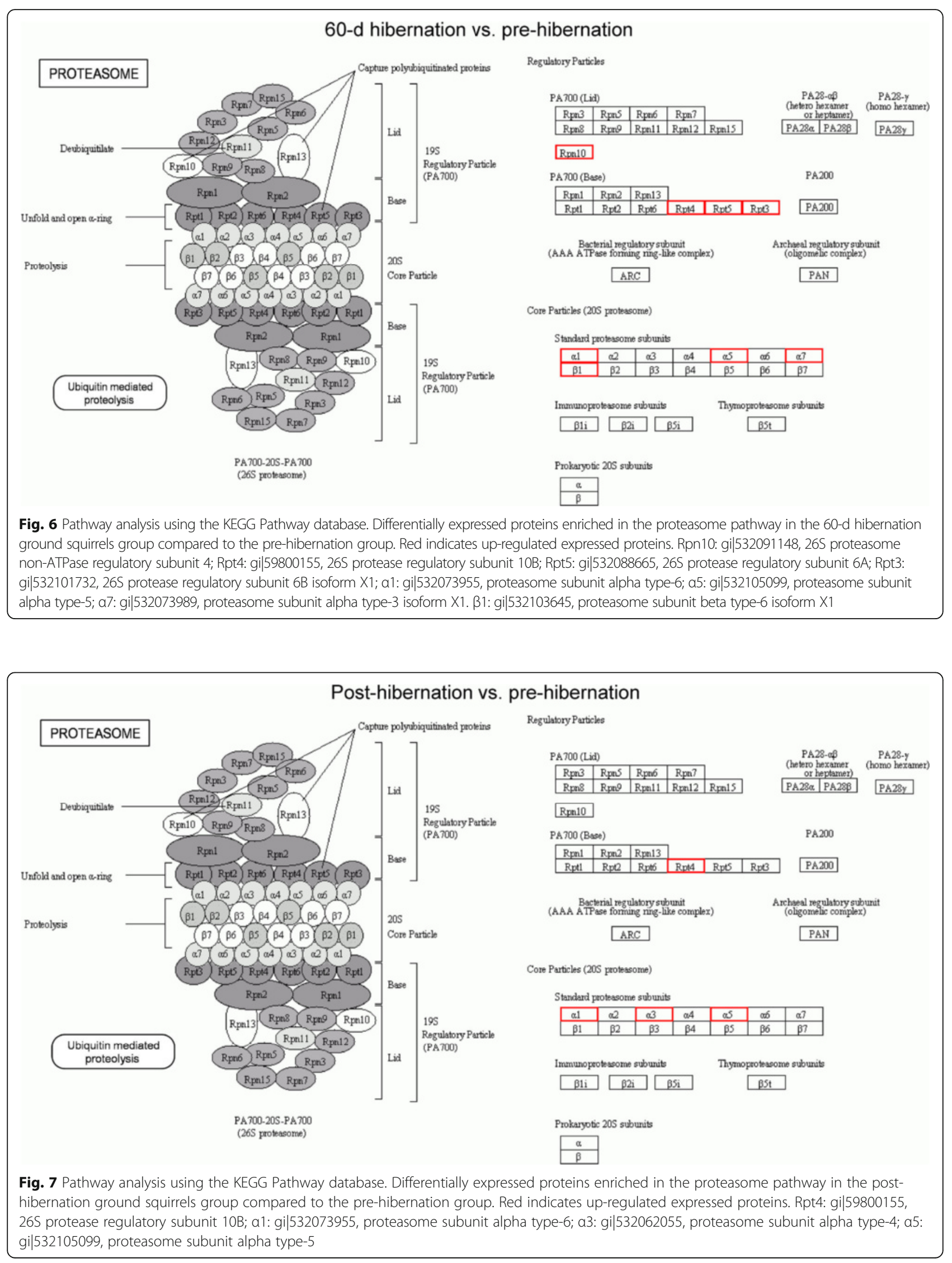


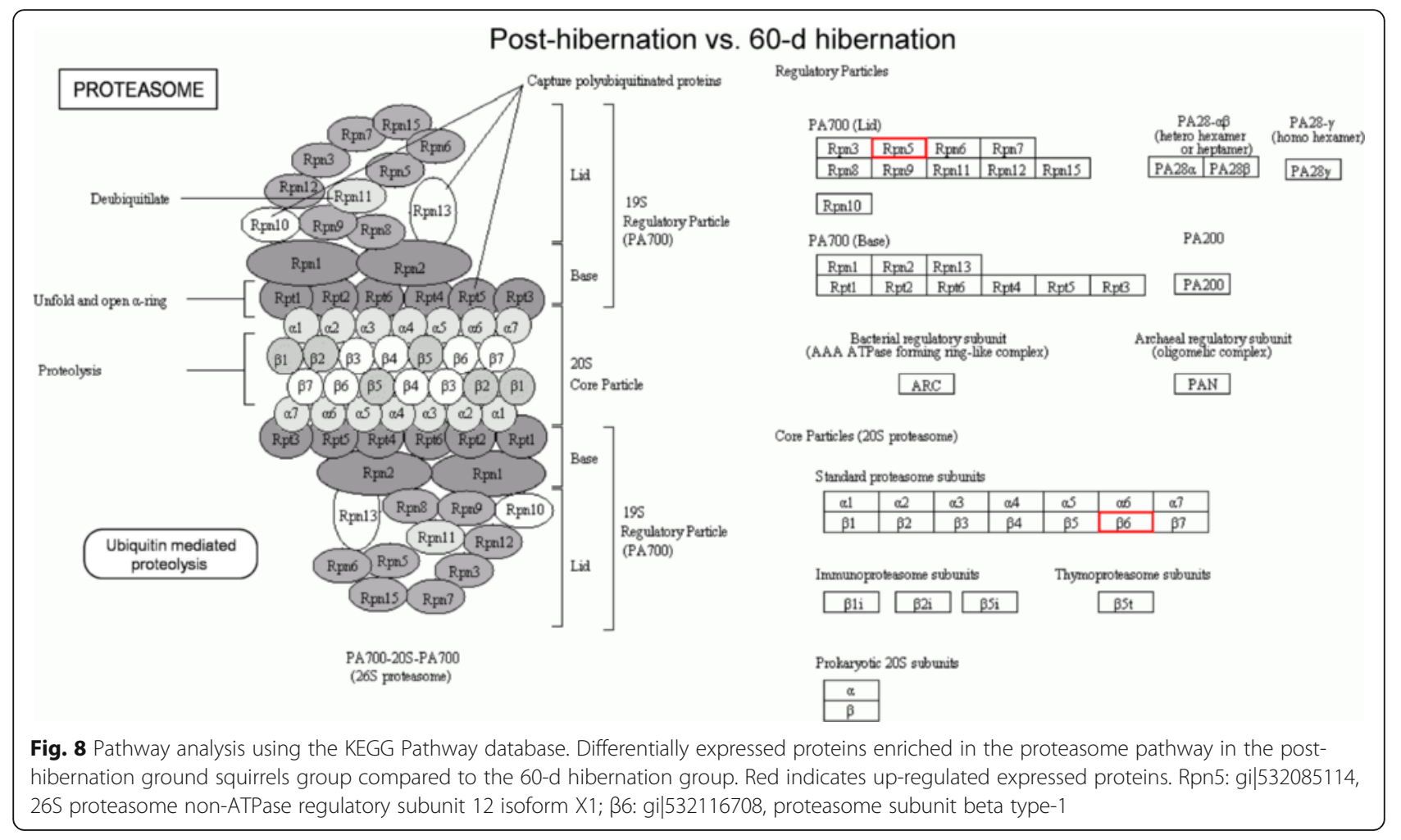

or spaceflight [40]. This study found that the number of up-regulated proteins was much higher in posthibernation (248) than that of the proteins in 60-d hibernation group (96). Moreover, most of up-regulated proteins were mainly involved in protein binding, catalytic activity, transporter activity, enzyme regulator activity and other metabolic processes, which might be due to that the ground squirrels are recovering and likely produce these types of proteins rapidly upon resuming feeding and activity in 2 days awake after posthibernation. These results indicated that protein synthesis was even strengthened in late hibernation period, which related to the regulation of contractile function. Our results agree well with the previous findings that the increase of protein synthesis to preserve and augment muscle mass in late winter was observed through direct measurements of protein synthesis by the in vivo SUnSET technique [41], which concurs with the finding here of accelerated synthesis in the later hibernation time point.

Here, we showed that there were 3 and 10 proteins with protein synthesis function significantly up-regulated in the 60-d hibernation group and post-hibernation group, respectively, relative to the pre-hibernation group (Fig. 2). Specifically, 60S ribosomal protein L39-like which was a structural constituent of ribosome participated in RNA binding and translation bioprocess, and polyadenylate-binding protein 4 isoform $\mathrm{X} 1$, which was a RNA-binding protein and locates in cytoplasmic stress granule and nucleus participated in RNA catabolic process and translation, were both significantly increased in the 60-d hibernation group compared to the pre-hibernation group. Besides, all of the upregulated proteins were involved in translation, 7 of which were structural constituent of ribosome. In addition, elongation factor 1-beta isoform $X 2$ which participates in translational elongation biological process was found continuously up-regulated in 60-d and post-hibernation groups relative to the prehibernation ground squirrels (Table 1).

In fact, down-regulated $40 \mathrm{~S}$ ribosomal protein subunits in the 60-d hibernation ground squirrels, which bind to mRNA and modulate of the initiation phase of mRNA translation [42], suggested that the initiation of translation in protein synthesis was inhibited to a certain extent in hibernation. Consistent with our study, previous report demonstrated that mice homozygous for translation elongation factor $1 \mathrm{~A}(\mathrm{eEF} 1 \mathrm{~A})$ deletion in muscle corresponds precisely to the onset of the wasted phenotype, characterized by muscle atrophy [43]. In addition, another serine-threonine kinase, serum- and glucocorticoid-regulated kinase 1 (SGK1), was upregulated during hibernation in 13-lined ground squirrel (Ictidomys tridecemlineatus) and contributed to protection from loss of muscle mass via an increased protein synthesis [44]. Hibernation factors including RMF 

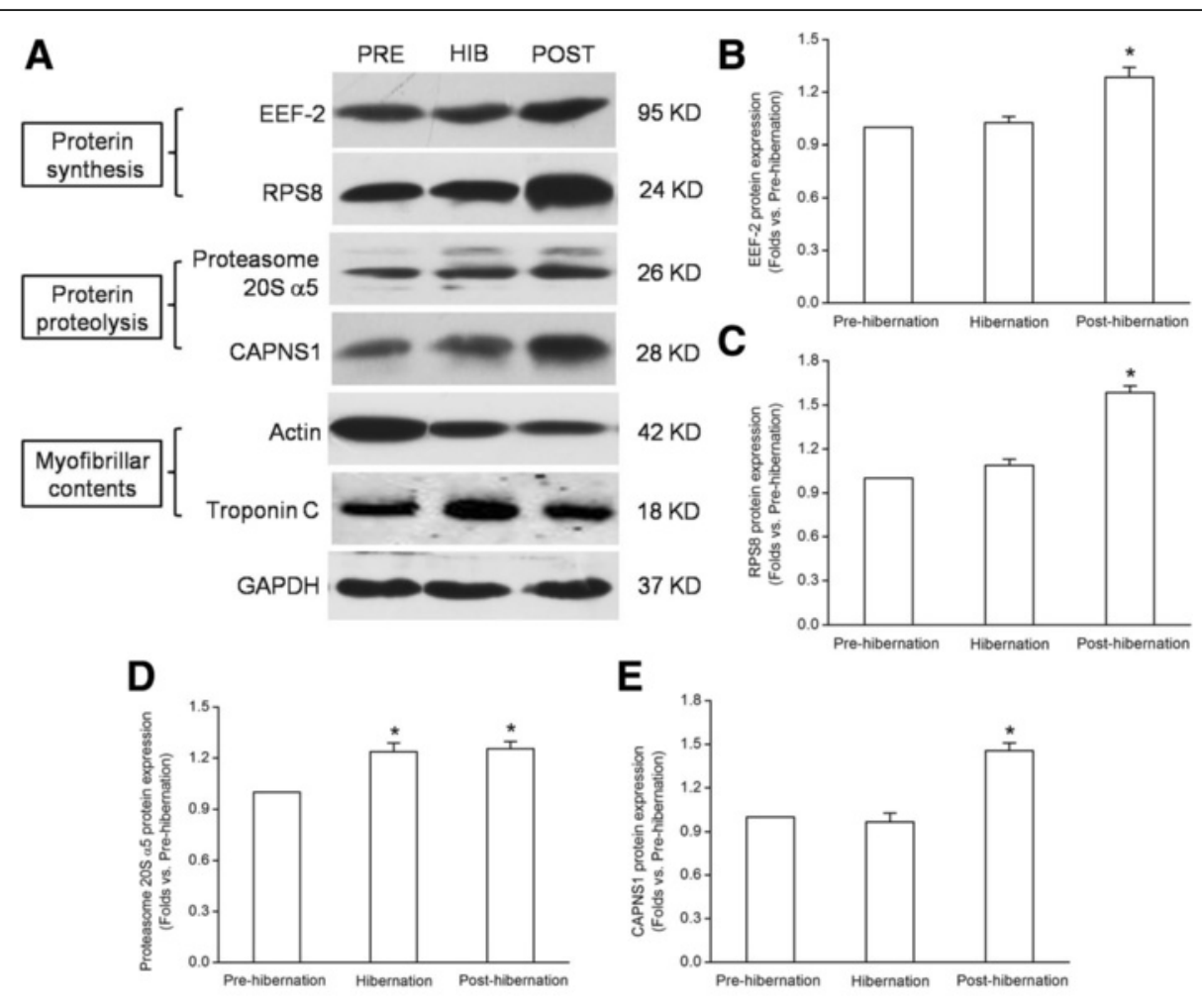

E
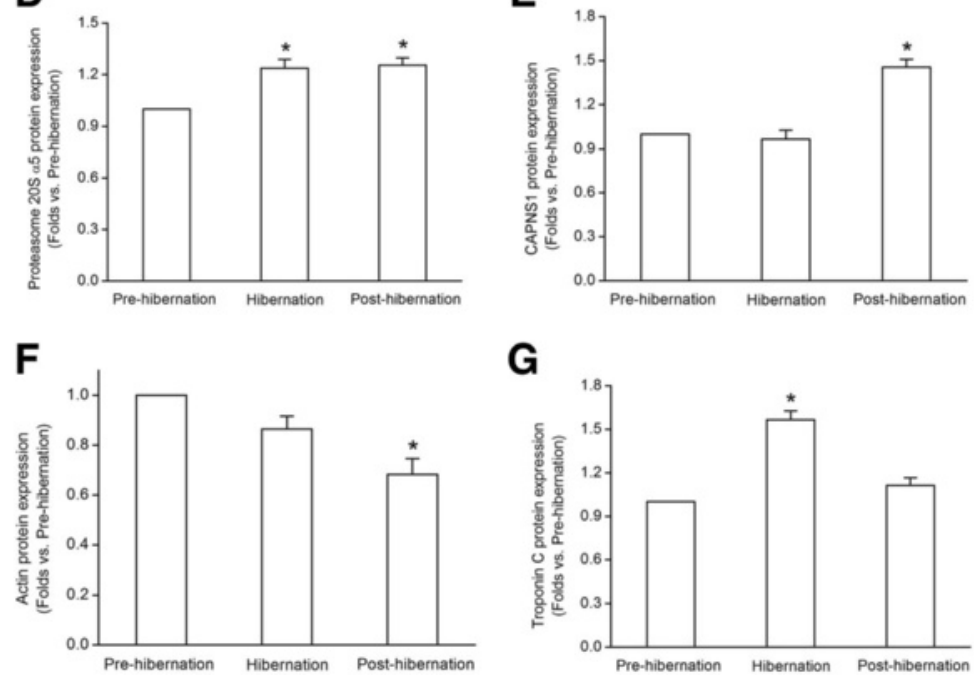

G

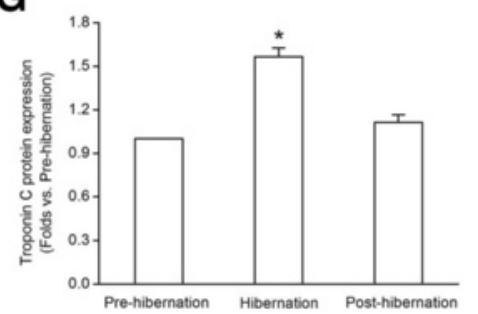

Fig. 9 Western blot analysis of 6 differentially expressed proteins. a Representative bands of EEF-2, RPS8, proteasome 20S a5, CAPNS1, actin and troponin $\mathrm{C}$ in the soleus of pre-hibernation (PRE), hibernation (HIB) and post-hibernation (POST) squirrels. b-g Summarized data of protein quantity normalized by GAPDH in different groups. Values are mean $\pm \mathrm{SEM}$. ${ }^{*} P<0.05$ versus pre-hibernation group

(ribosome modulation factor), HPF (hibernation promoting factor) and YfiA (protein which inactivates ribosomes as $70 \mathrm{~S}$ monomers) turn off protein synthesis via binding to the ribosome [45]. However, since the protein synthesis is a process of energy dissipation and the hibernating animals live in low temperature, fasting, or eating less state, we consider that the theory that the hibernating animals during prolonged period of immobilization and starvation by promoting protein synthesis to overcome muscular atrophy may not occupy a dominant position. Indeed, the rate of protein synthesis in vivo in the brain of torpid ground squirrels was just $0.04 \%$ of that in active squirrels [46]. Together these findings suggest that protein synthesis was not inhibited during prolonged hibernation, which might play an important role in preventing atrophy in SOL of ground squirrels during hibernation.
The rates of protein degradation decreased significantly in hibernation and post-hibernation group as compared with the pre-hibernation group (Fig. 10). Different protein degradation pathways may be involved in sarcomeric protein loss in muscle atrophy. The ubiquitin-proteasome system and the autophagylysosome pathway are the major protein degradation systems involved in this process [47]. Moreover, calpains, a family of $\mathrm{Ca}^{2+}$-dependent proteases, play an initiating role in the protein degradation process and cause rapid and complete loss of Z-disk while activated by calcium.

In this study, we investigated that 10 and 14 proteins with protein proteolysis function were found significantly up-regulated in the 60-d hibernation group and posthibernation group, respectively, relative to the prehibernation group (Fig. 2). Two-thirds of the dysregulated 

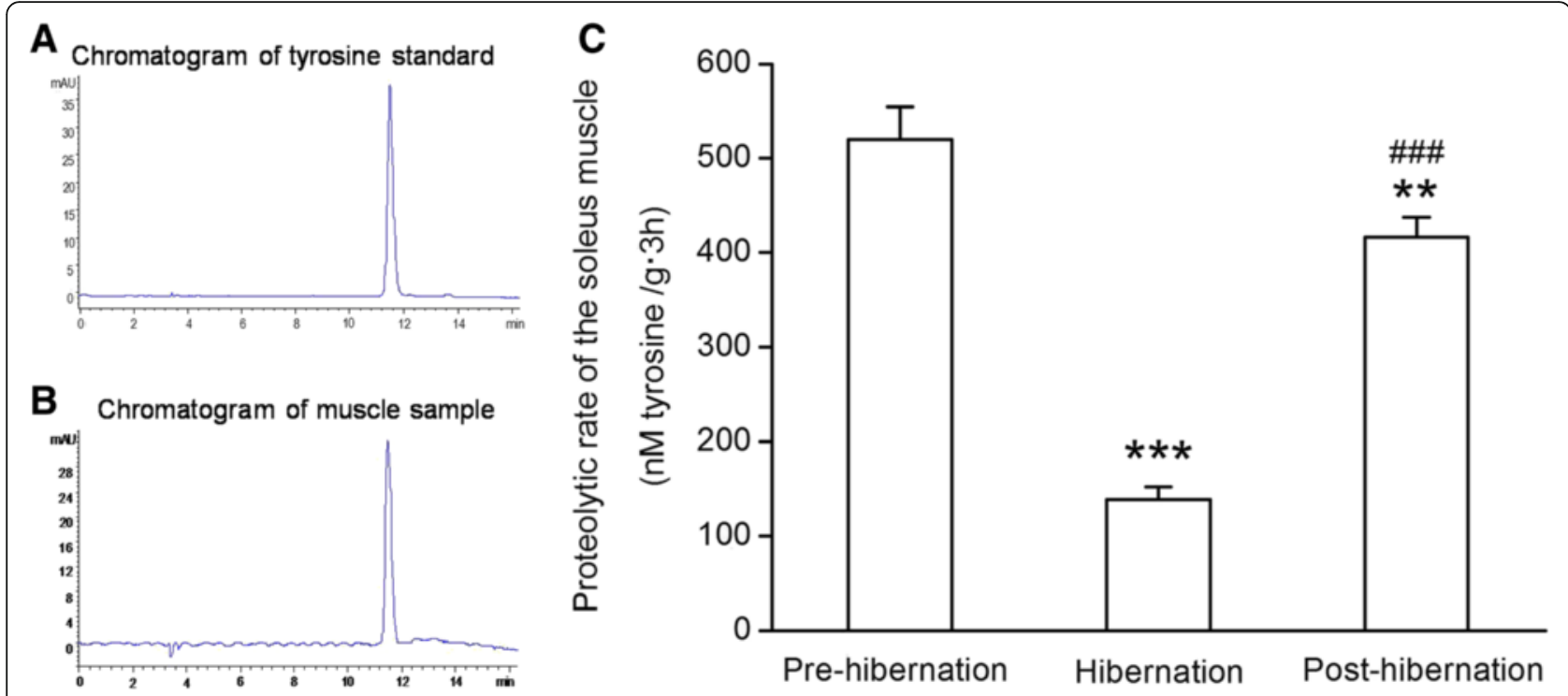

Fig. 10 a: Representative chromatogram of tyrosine standard. b: Representative chromatogram of muscle sample. c: Total protein proteolytic rate of the soleus muscle in ground squirrels from pre-hibernation, $60-d$ and post-hibernation groups. Values are means \pm SEM, $n=6$ in each group. ${ }^{* *} P<0.01$ and ${ }^{* *} P<0.001$ versus pre-hibernation group. \#\#\# $<0.001$ versus hibernation group

proteins were involved in ubiquitin-proteasome pathway and calpains pathway. Besides, proteasome subunit alpha type-5, proteasome subunit alpha type- 6 and $26 \mathrm{~S}$ protease regulatory subunit $10 \mathrm{~B}$ were found continuously upregulated in the 60-d and post-hibernation groups relative to the pre-hibernation ground squirrels (Table 2). These results indicated that ubiquitin-proteasome proteolysis was enhanced during prolonged hibernation. Actin, myosin heavy chains (in atrophying skeletal muscle), myosin light chains, members of the troponin family and telethonin were confirmed to be the ubiquitin-proteasome system substrates [48]. Telethonin, a substrate of the ubiquitin-proteasome system, was significantly downregulated in the 60-d hibernation group compared to the pre-hibernation group. It is noteworthy that ubiquitin carboxyl-terminal hydrolase isozyme L3 was 1.591 -fold increase in post-hibernation ground squirrels compared to pre-hibernation group. Similar with non-hibernators, the ubiquitin carboxy-terminal hydrolase L1 (UCHL1), functioning as an ubiquitin ligase and a mono-ubiquitin stabilizer, were also up-regulated in mice during hindlimb unloading [14], which suggest that ubiquitin carboxylterminal hydrolase might be activated in disuse. However, torpor may limit proteolysis in accordance with lower metabolic demands in livers of hibernating goldenmantled ground squirrels (Spermophilus lateralis) [49]. Importantly, calpastatin, an endogenous inhibitor of calpains, was found significantly up-regulated in the post-hibernation ground squirrels compared to the prehibernation group in present study, which is in consistent with our previous experimental report, in which the protein expression validation of calpastatin had been detected by western blot analyses, demonstrating the same result that inhibition of calpain activity and consequently calpain-mediated protein degradation by highly elevated calpastatin protein expression levels may be an important mechanism for preventing muscle protein loss during hibernation [15]. Nevertheless, calpain small subunit 1 also showed a significant increase in the posthibernation ground squirrels compared to the prehibernation group from proteomic analysis. Calpains are heterodimers containing an identical $28-\mathrm{kDa}$ regulatory small subunit and a distinct $80-\mathrm{kDa}$ catalytic large subunit. Effective inhibition of the calpains by calpastatin requires that calpastatin binds specifically to the domain II or IV of large subunit of calpains in a $\mathrm{Ca}^{2+}$ dependent manner [50]. Hence, it appears reasonable to assume that calpains are inhibited at the level of enzymatic activity rather than the protein expression, and the increase of calpains expression make it possible that hibernating ground squirrels can get energy via the proteolysis of myofibrillar proteins to get through the energy crisis, while the degree of protein proteolysis can be also regulated by the enzymatic activity when squirrels do not need the muscle protein supply energy, thereby minimizing the muscular atrophy of disuse.

Collectively, these results suggested that the ubiquitin-proteasome catabolic pathway might be strengthened and be responsible for limited atrophy in the late hibernating period of Daurian ground squirrels. Moreover, calpains pathway might be regulated via the enzyme activity in hibernating ground squirrels, which subsequently regulate the ubiquitin-proteasome catabolic pathway and even the level of protein proteolysis 
of the whole body. Although recent study emphasizes autophagy-lysosome as another important proteolytic pathway in triggering the early stages of atrophy [47], no protein related to autophagy-lysosome pathway was detected proteomics differentially expressed in our study. Taken together, our study suggested that the limited SOL atrophy happened in the late hibernating period might be the result of activation of ubiquitin-proteasome catabolic pathway, and the effect of protecting atrophy in SOL during hibernation might be due to the inhibition of calpains and autophagy-lysosome proteolytic pathways.

\section{Conclusions}

In this study, we present a proteomic analysis in soleus muscle of Daurian ground squirrels for the first time. These findings not only provide novel insights into the myofibrillar remodeling, which was marked by dysregulated contractile proteins (myosins and actin) and regulatory proteins (troponin and tropomodulin) and maintain of most sarcomeric structural proteins, contributes to a protective effect that prevents muscle atrophy in spite of prolonged disuse during hibernation, but also provide the first experimental evidence that the total proteolysis rates of soleus in hibernating ground squirrels is decreased. Moreover, the strengthened ubiquitin-proteasome pathway and calpains pathway related to the protein degradation, associated with higher level of calpastatin, contributes to maintain of most myofibrillar proteins in hibernation. Although the number of differentially expressed proteins associated with protein degradation is much more than those associated with protein synthesis in hibernation, the increased part may be partially offset by the strengthened ubiquitin-proteasome catabolic pathway,which together with partial inhibition of calpains might play a critical role in maintain of myofibrillar proteins and provide a foundation for elucidating the mechanisms of prevention of the disuse atrophy in skeletal muscle in nonhibernation animals.

\section{Limitations of the study}

The iTRAQ-based proteomic analysis should have biological triplicates, however, we have validated the expression levels of some proteins using western blot technology to make up for this deficiency. In addition, iTRAQ-based quantitative proteomic analysis does not involve the differentially modulation of post-translational modification of proteins which are critical in adaptation to hibernating state. Besides, the proteins and pathways identified by computerbased statistical algorithms also need to be verified experimentally in future.

\section{Additional file}

Additional file 1: Table S1. Summary table showing a full list of identified proteins and their relative expression in SOL muscle among pre-hibernation, 60-d hibernation and 112-d hibernation groups in Daurian ground squirrels identified by iTRAQ. (DOCX $101 \mathrm{~kb}$ )

\section{Acknowledgements}

This study was supported by funds from the National Nature Science Foundation of China (31270455 and 31200862), the Postdoctoral Research Fund of Shaanxi Province,the Shaanxi Province Natural Science Basic Research Program (2016JQ3014),the Postdoctoral Science Foundation of China (2015 M580869).

\section{Funding}

The National Nature Science Foundation of China (31270455)-Gao YF. The National Nature Science Foundation of China (31200862)-Chang H. The Postdoctoral Research Fund of Shaanxi Province-Chang $\mathrm{H}$. The Shaanxi Province Natural Science Basic Research Program (2016JQ3014) -Chang $\mathrm{H}$.

The Postdoctoral Science Foundation of China (2015 M580869) -Chang H. Gao YF designed the study wrote the manuscript. Chang $\mathrm{H}$ performed the experiments, analyzed the data and wrote the manuscript.

\section{Availability of data and materials}

We wish to share our data in Additional file 1: Table S1 Full list of UP (fold-change $>1.5$ ) or DOWN (fold-change $<0.8$ ) regulated proteins in 3 animal groups.

\section{Authors' contributions}

Conceived and designed the experiments: SFJ, YFG, HC. Performed the experiments: HC, SFJ, KD, HPW, SHX. Analyzed the data: HC and SFJ. Wrote the paper: HC, YFG. All authors read and approved the final manuscript.

\section{Competing interests}

The authors declare that they have no competing interests.

\section{Consent for publication}

Not applicable.

\section{Ethics approval}

All procedures were approved by the Laboratory Animal Care Committee of the P. R. China Ministry of Health and the Northwest University Ethics Committee.

Received: 11 July 2016 Accepted: 1 November 2016

Published online: 08 November 2016

\section{References}

1. Wang Y, Pessin JE. Mechanisms for fiber-type specificity of skeletal muscle atrophy. Curr Opin Clin Nutr Metab Care. 2013;16(3):243-50.

2. Narici MV, de Boer MD. Disuse of the musculo-skeletal system in space and on earth. Eur J Appl Physiol. 2011;111(3):403-20.

3. Adams GR, Caiozzo VJ, Baldwin KM. Skeletal muscle unweighting: spaceflight and ground-based models. J Appl Physiol (1985). 2003;95(6): 2185-201

4. Baldwin KM, White TP, Arnaud SB, et al. Musculoskeletal adaptations to weightlessness and development of effective countermeasures. Med Sci Sports Exerc. 1996;28(10):1247-53.

5. Hvid LG, Ortenblad N, Aagaard P, Kjaer M, Suetta C. Effects of ageing on single muscle fibre contractile function following short-term immobilisation. J Physiol. 2011;589(Pt 19):4745-57.

6. Hvid LG, Suetta C, Aagaard P, Kjaer M, Frandsen U, Ortenblad N. Four days of muscle disuse impairs single fiber contractile function in young and old healthy men. Exp Gerontol. 2013;48(2):154-61.

7. Lawler JM, Kunst M, Hord JM, et al. EUK-134 ameliorates nNOSmu translocation and skeletal muscle fiber atrophy during short-term mechanical unloading. Am J Physiol Regul Integr Comp Physiol. 2014; 306(7):R470-82. 
8. Seo Y, Lee K, Park K, Bae K, Choi I. A proteomic assessment of muscle contractile alterations during unloading and reloading. J Biochem. 2006; 139(1):71-80.

9. Steffen JM, Musacchia XJ. Disuse atrophy, plasma corticosterone, and muscle glucocorticoid receptor levels. Aviat Space Environ Med. 1987; 58(10):996-1000.

10. Thomason DB, Herrick RE, Surdyka D, Baldwin KM. Time course of soleus muscle myosin expression during hindlimb suspension and recovery. J Appl Physiol (1985). 1987;63(1):130-7.

11. Kachaeva EV, Shenkman BS. Various jobs of proteolytic enzymes in skeletal muscle during unloading: facts and speculations. J Biomed Biotechnol. 2012;2012:493618.

12. Tinker DB, Harlow HJ, Beck TD. Protein use and muscle-fiber changes in free-ranging, hibernating black bears. Physiol Zool. 1998;71(4):414-24.

13. Shanfeng Jiang YG, Yangmei Zhang KL, Goswami HWN. The research on the formation mechanism_x000A_of extraordinary oxidative capacity of x000A_skeletal muscle in hibernating ground_x000A_squirrels (Spermophilus dauricus). Zool Stud. 2015;54:46.

14. Wang F, Zhang P, Liu H, Fan M, Chen X. Proteomic analysis of mouse soleus muscles affected by hindlimb unloading and reloading. Muscle Nerve. 2015;52(5):803-11.

15. Yang CX, He Y, Gao YF, Wang HP, Goswami N. Changes in calpains and calpastatin in the soleus muscle of Daurian ground squirrels during hibernation. Comp Biochem Physiol A Mol Integr Physiol. 2014;176:26-31.

16. Gao YF, Wang J, Wang HP, et al. Skeletal muscle is protected from disuse in hibernating dauria ground squirrels. Comp Biochem Physiol A Mol Integr Physiol. 2012;161(3):296-300.

17. Lohuis TD, Harlow HJ, Beck TD. Hibernating black bears (Ursus americanus) experience skeletal muscle protein balance during winter anorexia. Comp Biochem Physiol B Biochem Mol Biol. 2007;147(1):20-8.

18. Fedorov VB, Goropashnaya AV, Toien $\mathrm{O}$, et al. Elevated expression of protein biosynthesis genes in liver and muscle of hibernating black bears (Ursus americanus). Physiol Genomics. 2009;37(2):108-18.

19. Andres-Mateos E, Brinkmeier H, Burks TN, et al. Activation of serum/ glucocorticoid-induced kinase 1 (SGK1) is important to maintain skeletal muscle homeostasis and prevent atrophy. EMBO Mol Med. 2013;5(1):80-91.

20. Dang K, Li YZ, Gong LC, et al. Stable atrogin-1 (Fbxo32) and MuRF1 (Trim63) gene expression is involved in the protective mechanism in soleus muscle of hibernating Daurian ground squirrels (Spermophilus dauricus). Biol Open. 2016;5(1):62-71.

21. Dang K, Feng B, Gao YF, et al. Muscle protection during hibernation: Role of atrogin-1 and MuRF1, and fiber type transition in Daurian ground squirrels. Can J Zool. 2016;94(9):619-29.

22. Li T, Brouwer M. Gene expression profile of hepatopancreas from grass shrimp Palaemonetes pugio exposed to cyclic hypoxia. Comp Biochem Physiol Part D Genomics Proteomics. 2013;8(1):1-10.

23. Cui J, Wang H, Liu S, Qiu X, Jiang Z, Wang X. Transcriptome analysis of the gill of Takifugu rubripes using Illumina sequencing for discovery of SNPs. Comp Biochem Physiol Part D Genomics Proteomics. 2014;10:44-51.

24. Chang H, Sheng JJ, Zhang L, et al. ROS-induced nuclear translocation of calpain-2 facilitates cardiomyocyte apoptosis in tail-suspended rats. J Cell Biochem. 2015;116(10):2258-69.

25. Tiao G, Fagan J, Roegner $\mathrm{V}$, et al. Energy-ubiquitin-dependent muscle proteolysis during sepsis in rats is regulated by glucocorticoids. J Clin Invest. 1996;97(2):339-48.

26. Long M, Zhao J, Li T, et al. Transcriptomic and proteomic analyses of splenic immune mechanisms of rainbow trout (Oncorhynchus mykiss) infected by Aeromonas salmonicida subsp. salmonicida. J Proteomics. 2015;122:41-54.

27. Rahimov F, Kunkel LM. The cell biology of disease: cellular and molecular mechanisms underlying muscular dystrophy. J Cell Biol. 2013;201(4):499-510.

28. Lee K, Park JY, Yoo W, et al. Overcoming muscle atrophy in a hibernating mammal despite prolonged disuse in dormancy: proteomic and molecular assessment. J Cell Biochem. 2008;104(2):642-56.

29. Miller MS, Toth MJ. Myofilament protein alterations promote physical disability in aging and disease. Exerc Sport Sci Rev. 2013;41(2):93-9.

30. Akhter $\mathrm{S}$, Jin JP. Distinct conformational and functional effects of two adjacent pathogenic mutations in cardiac troponin I at the interface with troponin T. FEBS Open Bio. 2015;5:64-75.

31. Salanova M, Gelfi C, Moriggi M, et al. Disuse deterioration of human skeletal muscle challenged by resistive exercise superimposed with vibration: evidence from structural and proteomic analysis. FASEB J. 2014;28(11):4748-63.

32. Rao JN, Madasu Y, Dominguez R. Mechanism of actin filament pointed-end capping by tropomodulin. Science. 2014:345(6195):463-7.

33. Gokhin DS, Tierney MT, Sui Z, Sacco A, Fowler VM. Calpain-mediated proteolysis of tropomodulin isoforms leads to thin filament elongation in dystrophic skeletal muscle. Mol Biol Cell. 2014;25(6):852-65.

34. Sussman MA, Baque S, Uhm CS, et al. Altered expression of tropomodulin in cardiomyocytes disrupts the sarcomeric structure of myofibrils. Circ Res. 1998;82(1):94-105.

35. Udaka J, Ohmori S, Terui T, et al. Disuse-induced preferential loss of the giant protein titin depresses muscle performance via abnormal sarcomeric organization. J Gen Physiol. 2008;131(1):33-41.

36. Salmov NN, Vikhlyantsev IM, Ulanova AD, et al. Seasonal changes in isoform composition of giant proteins of thick and thin filaments and titin (connectin) phosphorylation level in striated muscles of bears (Ursidae, Mammalia). Biochemistry (Mosc). 2015;80(3):343-55.

37. Garton FC, Seto JT, Quinlan KG, Yang N, Houweling PJ, North KN. alphaActinin-3 deficiency alters muscle adaptation in response to denervation and immobilization. Hum Mol Genet. 2014;23(7):1879-93.

38. Thijssen $\mathrm{VL}$, Borgers $\mathrm{M}$, Lenders $\mathrm{MH}$, et al. Temporal and spatial variations in structural protein expression during the progression from stunned to hibernating myocardium. Circulation. 2004;110(21):3313-21.

39. Mitch WE, Goldberg AL. Mechanisms of muscle wasting. The role of the ubiquitin-proteasome pathway. N Engl J Med. 1996;335(25):1897-905.

40. Fitts RH, Riley DR, Widrick JJ. Physiology of a microgravity environment invited review: microgravity and skeletal muscle. J Appl Physiol (1985). 2000;89(2):823-39.

41. Hindle AG, Otis JP, Epperson LE, et al. Prioritization of skeletal muscle growth for emergence from hibernation. J Exp Biol. 2015;218(Pt 2):276-84.

42. Gordon BS, Kelleher AR, Kimball SR. Regulation of muscle protein synthesis and the effects of catabolic states. Int J Biochem Cell Biol. 2013;45(10):2147-57.

43. Doig J, Griffiths LA, Peberdy D, et al. In vivo characterization of the role of tissue-specific translation elongation factor $1 \mathrm{~A} 2$ in protein synthesis reveals insights into muscle atrophy. FEBS J. 2013;280(24):6528-40.

44. Ivakine EA, Cohn RD. Maintaining skeletal muscle mass: lessons learned from hibernation. Exp Physiol. 2014;99(4):632-7.

45. Polikanov YS, Blaha GM, Steitz TA. How hibernation factors RMF, HPF, and YfiA turn off protein synthesis. Science. 2012;336(6083):915-8.

46. Frerichs $\mathrm{KU}$, Smith $\mathrm{CB}$, Brenner M, et al. Suppression of protein synthesis in brain during hibernation involves inhibition of protein initiation and elongation. Proc Natl Acad Sci U S A. 1998;95(24):14511-6.

47. Sandri M. Protein breakdown in muscle wasting: role of autophagylysosome and ubiquitin-proteasome. Int J Biochem Cell Biol. 2013; 45(10):2121-9.

48. Polge C, Attaix D, Taillandier D. Role of E2-Ub-conjugating enzymes during skeletal muscle atrophy. Front Physiol. 2015;6:59.

49. Velickovska V, van Breukelen F. Ubiquitylation of proteins in livers of hibernating golden-mantled ground squirrels, Spermophilus lateralis. Cryobiology. 2007;55(3):230-5.

50. Goll DE, Thompson VF, Li H, Wei W, Cong J. The calpain system. Physiol Rev. 2003;83(3):731-801.

\section{Submit your next manuscript to BioMed Central and we will help you at every step:}

- We accept pre-submission inquiries

- Our selector tool helps you to find the most relevant journal

- We provide round the clock customer support

- Convenient online submission

- Thorough peer review

- Inclusion in PubMed and all major indexing services

- Maximum visibility for your research

Submit your manuscript at www.biomedcentral.com/submit 